\title{
Modelling the evolution of organic carbon during its gas-phase tropospheric oxidation: development of an explicit model based on a self generating approach
}

\author{
B. Aumont ${ }^{1}$, S. Szopa ${ }^{1, *}$, and S. Madronich ${ }^{2}$ \\ ${ }^{1}$ Laboratoire Interuniversitaire des Systèmes Atmosphériques, UMR CNRS 7583, Universités Paris 7 et Paris 12, 94010 \\ Créteil Cedex, France \\ ${ }^{2}$ National Center for Atmospheric Res., Atmospheric Chemistry Division, P.O. Box 3000, Boulder, Colorado 80307, USA \\ *now at: Laboratoire des Sciences du Climat et de l'environnement, UMR CNRS CEA 1572, 91191 Gif-sur-Yvette, France
}

Received: 22 November 2004 - Published in Atmos. Chem. Phys. Discuss.: 11 February 2005

Revised: 26 May 2005 - Accepted: 26 May 2005 - Published: 22 September 2005

\begin{abstract}
Organic compounds emitted in the atmosphere are oxidized in complex reaction sequences that produce a myriad of intermediates. Although the cumulative importance of these organic intermediates is widely acknowledged, there is still a critical lack of information concerning the detailed composition of the highly functionalized secondary organics in the gas and condensed phases. The evaluation of their impacts on pollution episodes, climate, and the tropospheric oxidizing capacity requires modelling tools that track the identity and reactivity of organic carbon in the various phases down to the ultimate oxidation products, $\mathrm{CO}$ and $\mathrm{CO}_{2}$. However, a fully detailed representation of the atmospheric transformations of organic compounds involves a very large number of intermediate species, far in excess of the number that can be reasonably written manually. This paper describes (1) the development of a data processing tool to generate the explicit gas-phase oxidation schemes of acyclic hydrocarbons and their oxidation products under tropospheric conditions and (2) the protocol used to select the reaction products and the rate constants. Results are presented using the fully explicit oxidation schemes generated for two test species: n-heptane and isoprene. Comparisons with wellestablished mechanisms were performed to evaluate these generated schemes. Some preliminary results describing the gradual change of organic carbon during the oxidation of a given parent compound are presented.
\end{abstract}

Correspondence to: $\mathrm{B}$. Aumont

(aumont@lisa.univ-paris12.fr)

\section{Introduction}

Volatile organic compounds (VOCs) emitted in the atmosphere are oxidized in complex reaction sequences that produce a myriad of intermediates. The intermediates are typically organic radicals involved in radical oxidation chains (peroxy, oxy and Criegee radicals) and oxygenated secondary (i.e. produced in situ) species such as alcohols, aldehydes, ketones, nitrates, peroxides, carboxylic acids and peracids (e.g. Atkinson, 2000). These intermediates play a key role in the chemistry of the troposphere. For example, these organic intermediates are directly involved in the production of tropospheric ozone and in the $\mathrm{HO}_{\mathrm{x}}\left(\mathrm{OH}+\mathrm{HO}_{2}\right)$ and $\mathrm{NO}_{\mathrm{x}}\left(\mathrm{NO}+\mathrm{NO}_{2}\right)$ budgets on regional and global scales (e.g. Seinfeld and Pandis, 1998; Finlayson-Pitts and Pitts, 2000, and references therein). Furthermore, many secondary organic species are multifunctional with low vapour pressure. These semi-volatile compounds lead to the production of secondary organic aerosol (SOA) by nucleation and/or condensation on pre-existing aerosols (e.g. Pankow et al., 2001; Hoffmann et al., 1997; Odum et al., 1997; Bowman et al., 1997) and/or polymerisation (Kalberer et al., 2004; Tolocka et al., 2004). The SOA components can contribute to the absorption and scattering of solar radiation (Jacobson, 1999), as well as affect the hygroscopic behaviour of particles (Saxena et al., 1995) and therefore their ability to act as cloud condensation nuclei by changes in surface tension (Facchini et al., 1999, 2000) or growth rates of cloud droplets (Lohmann et al., 2004; Shantz et al., 2003). Most secondary VOCs are water soluble, i.e. associated with high Henry's law coefficients. A significant fraction of secondary organics thus dissolves in the aqueous droplets during cloud

(C) 2005 Author(s). This work is licensed under a Creative Commons License. 


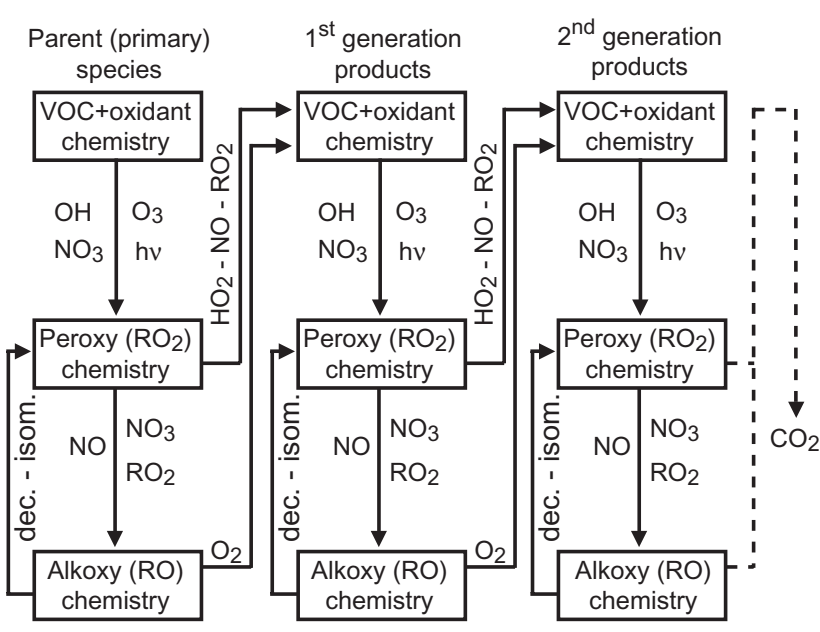

Fig. 1. Simplified representation of the reaction sequences involved in the tropospheric VOC oxidation.

events. This dissolved organic matter directly or indirectly interacts with the aqueous chemistry of radical, non metal and metal ion and oxidant pools (e.g. Faust, 1994; Ervens et al., 2003). Organic chemistry inside clouds may therefore modify the chemical budget of both aqueous and gas phases. For example, some organics can have an inhibiting effect on aqueous Fe-catalyzed $S^{\mathrm{IV}}$ oxidation (Wolf et al., 2000), and aqueous VOC oxidation can have a significant impact on the tropospheric ozone budget (Monod et al., 1999). Organic oxidation inside clouds may also be an additional source of SOA, after the evaporation of the cloud droplets (Blando and Turpin, 2000). Clearly, these and other processes involving organic intermediates may have significant effects on atmospheric reactivity, composition, and radiative budgets on wide-ranging geographic scales. However, the magnitude of these effects remains poorly understood, due largely to a critical lack of information concerning the detailed composition of the highly functionalized secondary organics in the gas and condensed phases.

Three-dimensional chemistry-transport models (e.g. those used for studying pollution episodes, regional and global oxidants, and climate) typically represent organic chemistry with highly simplified mechanisms that include the initial reactions of a few hydrocarbons and only a very limited subset of surrogate or lumped species to represent the intermediates (e.g. Gery et al., 1989; Stockwell et al., 1990, 1997; Bey et al., 2001; Brasseur et al., 1998; Poisson et al., 2000). These simplifications are frequently adequate to represent the nearfield gas phase reactivity (e.g. ozone formation in the vicinity of emission sources), but fall short of providing the chemical speciation necessary for a detailed understanding of the gas phase composition of aging air parcels, and of the contributions that organic intermediates make to the composition and properties of aerosols and clouds. In the past decade, major advances have been made towards the development of more explicit hydrocarbon oxidation mechanisms, such as the NCAR Master Mechanism (Madronich and Calvert, 1990; Aumont et al., 2000) with over 5000 reactions to represent the oxidation of about 20 emitted non-methane hydrocarbon, the SAPRC-99 mechanisms which describes the oxidation of about 400 emitted VOC (Carter, 2000), and the University of Leeds' Master Chemical Mechanism (MCM) with over 13000 reactions to describe the oxidation of about 100 emitted VOC (Jenkin et al., 1997, 2003; Saunders et al., 1997, 2003b). But even these large mechanisms neglect many reaction pathways by assuming that they individually make only a minor contribution, though it remains unclear whether their cumulative contributions could be important.

The fully explicit representation of hydrocarbon oxidation, from the initial compounds to the final product $\mathrm{CO}_{2}$, requires a very large number of chemical reactions and intermediate species, far in excess of the number that can be reasonably written manually. Nevertheless, several potential benefits from the availability of such full mechanisms can be identified. Knowledge of the precise chemical identity of intermediates enables the calculation of their atmospheric lifetimes and thus of their contribution to the gas phase reactivity of aging air masses (e.g. $\mathrm{HO}_{\mathrm{x}}$ and $\mathrm{NO}_{\mathrm{x}}$ budgets). Their vapour pressure and solubility can also be calculated and used to determine their partitioning to condensed phases, ultimately providing better estimates of the optical and microphysical properties of aerosols and clouds. Moreover, a fully explicit mechanism can serve as a benchmark for the systematic development and testing of simplified chemical mechanism for use in three-dimensional models where computer resources are limited. Finally, an explicit modelling approach offers increased opportunities for comparison with atmospheric measurements, particularly in view of recent advances in techniques for detecting many specific organic compounds.

Here, we describe a "self generating approach" to develop fully explicit gas-phase oxidation schemes of organic compounds under general tropospheric conditions. This approach was codified in a computer program, hereafter referred as the "generator" of the chemical schemes. The generator and the protocol used to select the reactions and the rate constants are similar to the approaches described by Jenkin et al. (1997) and Saunders et al. (2003a). The generator and the protocol are presented in Sects. 2 and 3, respectively. Section 4 presents some tests performed to evaluate the performance of the generated scheme by comparison with existing mechanisms. Finally, some preliminary results showing the major chemical characteristics of organic carbon during the oxidation of a given parent compound are presented (Sect. 5).

\section{The generator}

The construction of the chemical schemes generator is based on identifying all the reactions for a given primary (i.e. 


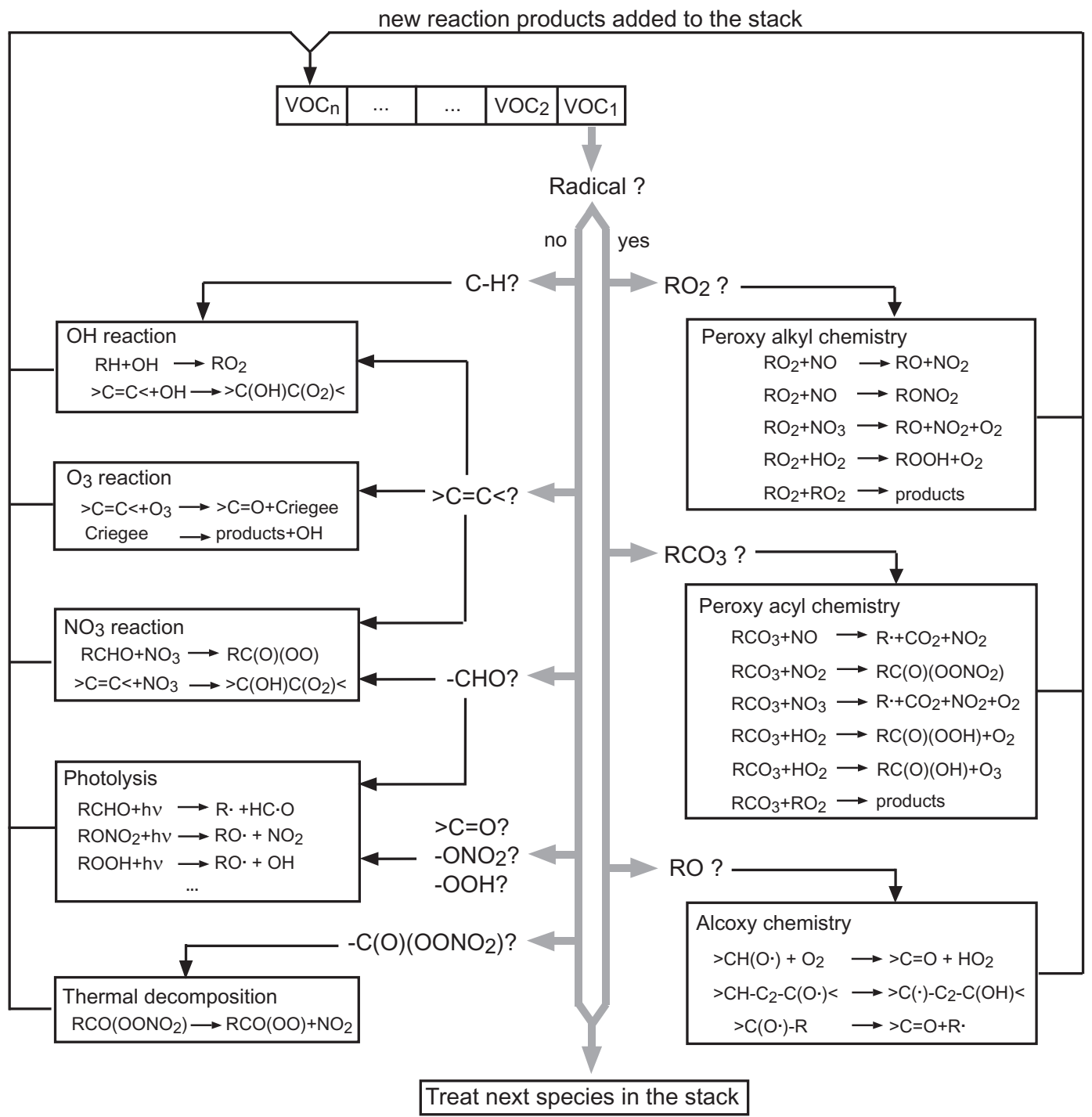

Fig. 2. Flow diagram of the generator.

emitted) species as well as for every intermediate up to $\mathrm{CO}$ or $\mathrm{CO}_{2}$ production. Atmospheric oxidation of organic compounds can be represented by a limited number of reaction types, repeated many times up to full oxidation of the given parent compound. With a few exceptions, these steps can be summarized as follow (see Fig. 1):

- The initiation of the radical organic chains by reaction with $\mathrm{OH}, \mathrm{NO}_{3}, \mathrm{O}_{3}$ or via bond breaking after the absorption of a photon. This first step generally leads to the formation of an organic peroxy radical $\left(\mathrm{RO}_{2}\right)$.

- Peroxy radical reactions with $\mathrm{NO}, \mathrm{NO}_{2}, \mathrm{NO}_{3}, \mathrm{HO}_{2}$ or with others $\mathrm{RO}_{2}$ radicals. These reactions either lead to a stable (i.e. a non radical) secondary organic species or to an organic alkoxy radical (RO).
- Alkoxy radical reaction with $\mathrm{O}_{2}$, unimolecular decomposition (i.e. C-C bond breaking) or isomerization. These reactions either lead to a stable secondary and/or to a new peroxy radical.

The redundancy in these reaction sequences is the basis of the generator.

The general philosophy followed to develop the generator is similar to the methods recently described by Saunders et al. (2003a). The generator can be viewed as a computer program that mimics the steps by which chemists might develop chemical schemes (i.e. writing the list of the reactions involved in the oxidation of a given species and their associated rate constants). These steps are illustrated Fig. 2 and can be summarized as follow. First the generator analyses the chemical structure of the molecule to identify the reactive sites and determine all reaction pathways. For each identified 


\section{Molecular structure}

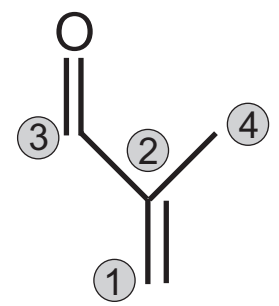

Bond matrix

\begin{tabular}{l|llll} 
& 1 & 2 & 3 & 4 \\
\hline 1 & 0 & 2 & 0 & 0 \\
2 & 2 & 0 & 1 & 1 \\
3 & 0 & 1 & 0 & 0 \\
4 & 0 & 1 & 0 & 0
\end{tabular}

Group vector

\begin{tabular}{l|l} 
& \\
\hline 1 & $\mathrm{CdH} 2$ \\
2 & $\mathrm{Cd}$ \\
3 & $\mathrm{CHO}$ \\
4 & $\mathrm{CH} 3$
\end{tabular}

Fig. 3. Description of molecular structures in the generator: the methacrolein example.

reaction, the generator then "searches" into a database of laboratory measurements of reaction rate constants and/or products to see if they may already be available. If not (as it is usually the case for the oxidation intermediates), an estimation of the rate constant and reaction products is made based on structure/activity relationships (see Sect. 3 below). The full reaction (reactants, products, stoichiometric coefficients, rate constant, and its temperature dependence) is then written in a file and the products, if new, are added to a "stack" for further reactions. These steps are repeated as long as species are present in the stack. The process stops when the stack is empty, which occurs when the full oxidation scheme has been written.

The molecular structure of the species needs to be known by the generator to select the appropriate set of reactions. This molecular structure is described using a matrix and a vector (see Fig. 3). The bond matrix provides the carbon skeleton of the molecule (each carbon is identified by an index; a bond between the $i$ th and $j$ th carbon is marked with non-zero values in the $(i, j)$ cell of the bond matrix). The group vector holds the information about the functional groups borne by each carbon. To avoid duplications, care is taken that each molecule (and its corresponding bond matrix and group vector) is written in a unique way based on the longest carbon chain and a pre-defined priority order for the functional groups.

The chemical schemes written by the generator are not conceptually different than those that could be written manually given enough time. However, several important advantages of the generator code should be noted:

- Its speed: explicit chemical schemes usually contain thousands of reactions and handwriting such schemes requires months of work. In fact, fully explicit chemical schemes are extremely large (see examples below) and the self-generating approach is probably the only realistic approach to develop such fully explicit schemes.

- Accuracy: it is almost impossible to write large schemes without introducing "errors" (for example in setting the rate constants or simply typographical errors in naming the species).
- Maintenance: updating chemical scheme can be a very tedious task. This is particularly true when the scheme must be updated as a result of a change in a structure/activity relationship. Updating the generator code is relatively straightforward and the new mechanism is easily re-generated.

The generator can therefore be viewed as an expert system, assimilating physico-chemical data from laboratory experiments (e.g. rate constants, vapor pressure, products yields) and estimating all the missing information. It is a very natural link between fundamental laboratory studies and the chemical models.

The current version of the generator treats the chemistry of every species (including $\mathrm{C}, \mathrm{H}, \mathrm{O}, \mathrm{N}$ atoms) except cyclic molecules. This includes alkanes (linear or branched), alkenes (conjugated or not), ethers, esters, alcohols, carbonyls, nitrates, peroxyacylnitrates, carboxylic acids, peracid, hydroperoxides, alkyl radicals, peroxy radicals and alkoxy radicals. The chemistry of cyclic molecules is currently read in a file (up to ring-opening) and corresponding mechanisms are added to the generator output file (see Sect. 3.10 below). The generator's code has been fully written in Fortran 77.

Despite the fairly limited number of reaction types implemented in the generator, the total number of species generated to describe the full oxidation of a given parent compound can be extremely large. Figure 4 shows the total number of species generated (hereafter denoted $N_{g}$ ) for the $\mathrm{n}$-alkanes series as a function of the number of carbons in the parent compound. $N_{g}$ grows from a few hundreds for propane to about 2.5 million species for octane. The increase follows an exponential law, with a growth factor of about 5.6 for each carbon added.

The chemistry codified in the generator can only lead to a limited number of functionalities. For the n-alkane series, possible groups for each carbon are: non-substituted alkyl, ketone (or aldehyde), alcohol, hydroperoxide, nitrate, peroxy radical and alkoxy radical. Four additional groups must be considered for the carbons at a terminal position viz.: carboxylic acid, peracid, peroxy acyl nitrate and peroxy acyl. 


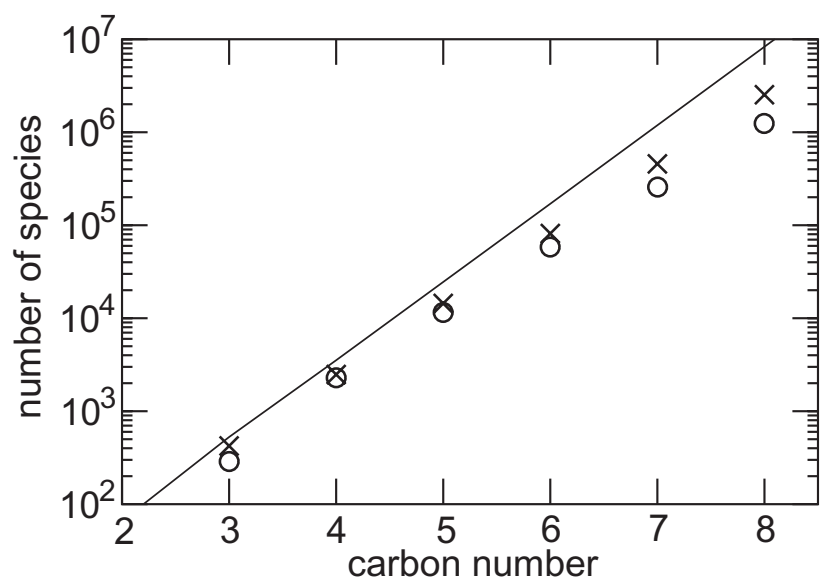

Fig. 4. Number of species created by the generator for the n-alkane series without a threshold for selecting reactions (cross) and with a 5\% branching threshold (circle). The line shows the maximum number of distinct species that can be produced for the n-alkane series by permuting all the possible functional groups codified in the generator.

Furthermore, we did not identify chemical pathways leading to a carbon bearing more than one functionality. Thus for the $\mathrm{n}$-alkane series, 11 and 7 distinct group substitutions can be identified for the terminal and internal carbon positions, respectively. Figure 4 shows the total number of "distinct" species that can be produced by permuting all the possible groups. For fairly large molecules (i.e. $\mathrm{C}>4$ ), the total number of distinct species (denoted $\Omega$ below) can be very well approximated by:

$\Omega \approx \sum_{i=2}^{n} \frac{1}{2}(11)^{2}(7)^{i-2}$,

where $n$ is the total number of carbons in the parent compound, the $\frac{1}{2}$ factor corrects approximately for symmetries, and the sum over $i$ takes into account the possible scissions of C-C bonds. The exponential growth of $N_{g}$ as a function of the chain length can thus be explained by the exponential increase of $\Omega$. The exponential growth factor of 5.6 found for the n-alkane series is however somewhat lower than the growth factor of $\approx 7$ predicted by Eq. (1). Some group distributions can indeed not be produced, due for example to $\mathrm{C}-\mathrm{C}$ bond scission before reaching them. Note however that for n-octane the total number of species produced by the generator still represents about $30 \%$ of all the possible functional group permutations (see Fig. 4). Similar results were found for other series (e.g. i-alkanes, 1-alkenes): the key factor determining the number of species and reactions generated is always the total number of carbon atoms in the parent molecule (see Fig. 5). Additional tests were performed to evaluate the sensitivity of $N_{g}$ to a given constrain for the activation of a particular reaction. Figure 4 shows that $N_{g}$ remains extremely large even if reactions contributing for less

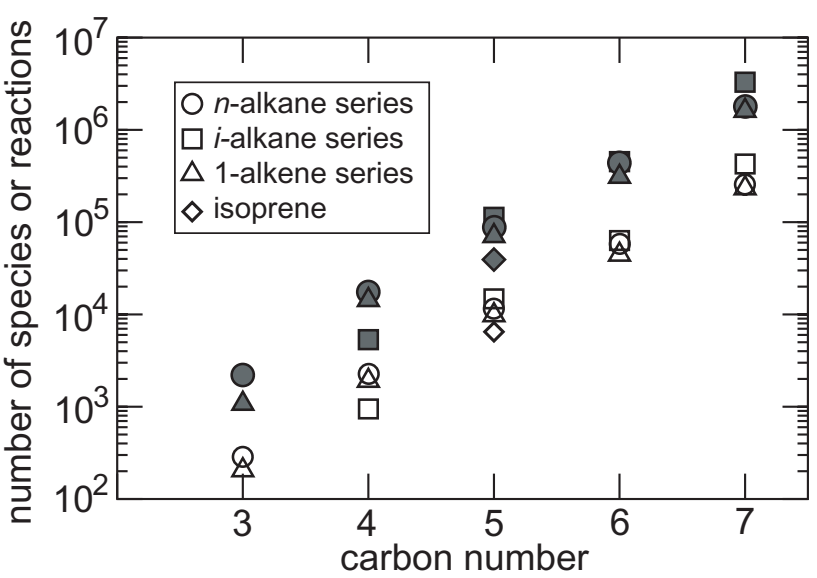

Fig. 5. Number of species (open symbols) and reactions (grey symbols) created by the generator for various series (using a 5\% threshold for selecting reactions).

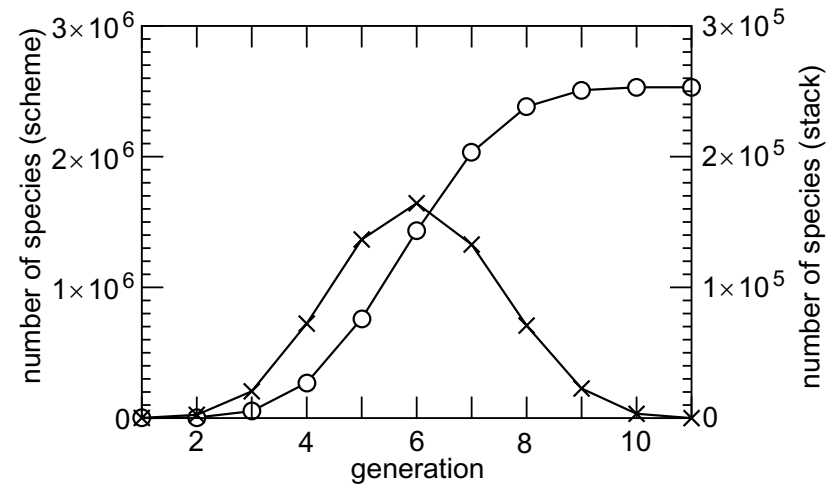

Fig. 6. Number of species generated as a function of the generation depth (circle, left scale) and species in the generator's stack (cross, right scale) for n-octane.

than $5 \%$ in the removal of a given species are ignored. We finally note that the number of the generated reactions is typically 10 times the number of species, i.e. reaching 25 million for the full oxidation of octane. Various tests were performed to reduce the number of species and reactions in the chemical scheme for 3-D applications. These tests are described in a companion paper (Szopa et al., 2005).

The number of generations (i.e. of successive non radical intermediates, see Fig. 1) required to fully oxidize a given parent compound was found to be slightly larger than the number of carbons in the parent compound. The main factor controlling this behaviour is that, on average, at least one generation is required per carbon to oxidize it from $-\mathrm{CH}_{2}-$ to $-\mathrm{CO}-$. Figure 6 shows the number of species generated for a given generation depth as well as the species remaining in the stack (i.e. species for which removal reactions still have to be written) for the n-octane case. The S-shaped and Gaussian profiles shown Fig. 6 were also found for the other 
species. These profiles can qualitatively be explained as follow. Each species in the generation $n$ leads to the production of a given number of species in the generation $n+1$ after reactions. For the first generations, these reaction products are mainly new species for which chemistry must be written. The total number of species as well as the number of species in the stack thus grows exponentially. However, a given reaction product can usually be produced by several distinct reaction pathways and must obviously be treated only once. Hence, after few generations, most reaction products are already treated in the scheme (i.e. other pathways already led to the same products) and the species is not added to the stack. The number of species in the stack starts to decrease, as well as the growth rate of the total number of generated species. As stated above, the chemical pathways involved in the full oxidation of every generated species are described when the stack is empty.

\section{Protocol description for the development of the or- ganic schemes}

Explicit chemical schemes would obviously be a faithful representation of oxidation mechanism occurring in the atmosphere if all reactions were known with a high accuracy. From the above section, it is clear that the number of species involved in such schemes far exceeds that for which direct measurements are available. Reaction pathways and rate constants must therefore be estimated for most species on the basis of their molecular structures. Numerous experimental data are currently available in the literature concerning the VOC oxidation. Compilations, data evaluations and recommendations for use in models are regularly provided by the NASA and IUPAC panels (e.g. DeMore et al., 1997; Atkinson et al., 1999) or in review papers (e.g. Atkinson, 1994; Atkinson and Arey, 2003; Orlando et al., 2003; Mellouki et al., 2003; Calvert et al., 2000). Reasonable estimates can be made by analogy to these known reactions, with the aid of several structure/activity relationships (SARs). The main feature of the generator described above is to codify the various estimation methods to produce consistent and comprehensive oxidation schemes on a systematic basis. We emphasize that the accuracy of the generated explicit schemes is linked directly to the accuracy of SAR predictions. Most rate constants are typically estimated with at least a factor 2 of uncertainty and some reaction pathways are highly hypothetical due to the lack of experimental data. Given these uncertainties, explicit organic schemes must rather be viewed as useful exploratory tools reflecting the current understanding of VOC oxidation than a new more precise representation of it. Note, however, that whenever the products and kinetics of a specific reaction are known directly from laboratory measurements, the generator gives priority to these experimental data rather than attempting to recalculate them from SARs.
Table 1. List of the organic radicals at steady state and their associated reaction products.

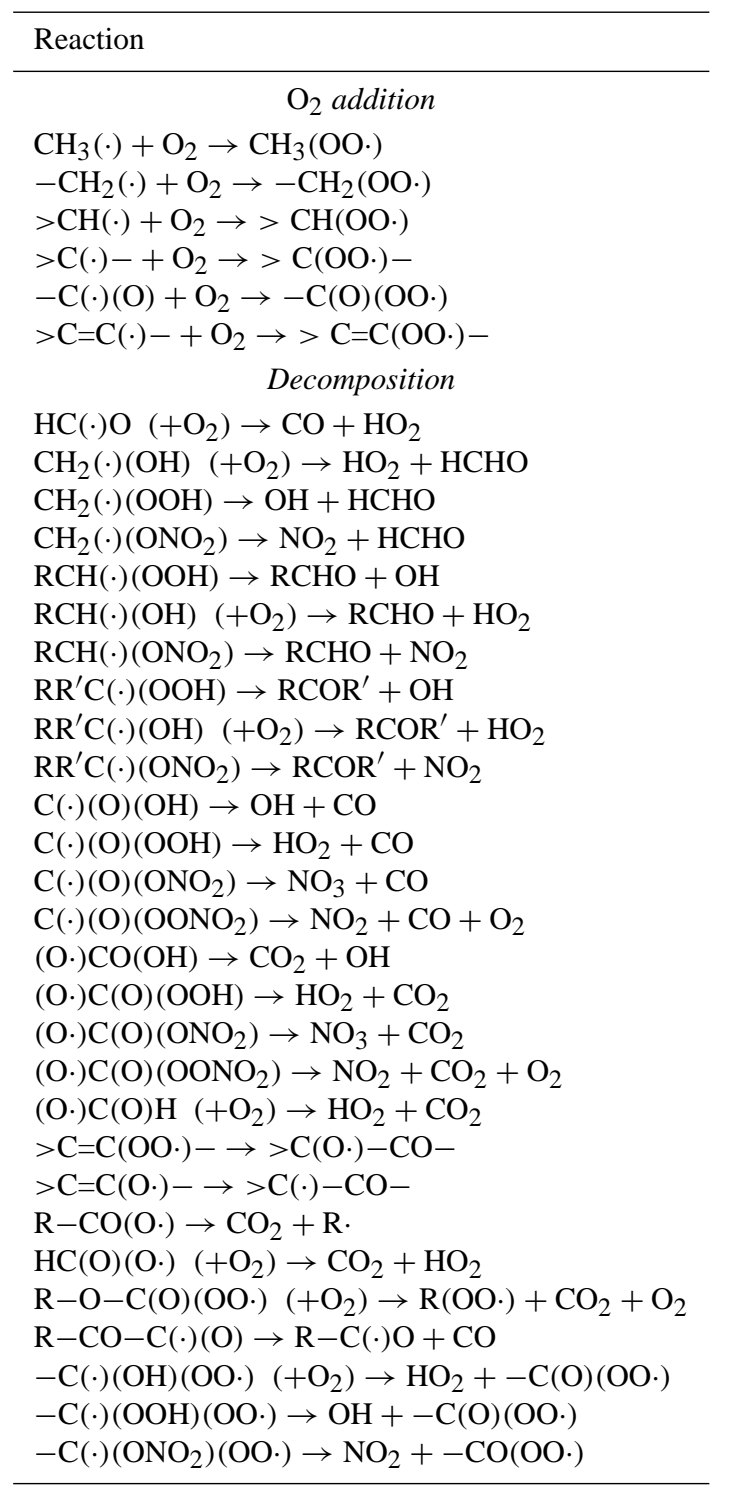

The protocol used in this study is very similar to the approaches already described by Jenkin et al. (1997), Saunders et al. (2003b) and Carter (2000) for the purpose of systematic development of organic schemes. Here we present only a brief overview of the protocol as implemented in the generator. A more detailed discussion concerning the rules used to set the chemical pathways as well as the SAR selected to estimate their associated rate constants can be found in Laval-Szopa (2003), based on data published before 2003 . Inorganic and $\mathrm{C}_{1}$ organic chemistry (i.e. methane oxidation) is out of the frame of the protocol presented here. Direct measurements are in fact available for these species and estimates are not necessary. Rate constants for the inorganic 
Table 2. Generic rate constants and branching ratios for alkene $+\mathrm{NO}_{3}$ reactions.

\begin{tabular}{|c|c|c|c|c|}
\hline Structures & 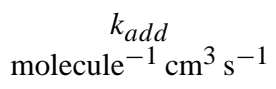 & Branching ratio & Reference compound & Notes \\
\hline \multicolumn{5}{|c|}{ alkenes } \\
\hline $\mathrm{CH}_{2}=\mathrm{CH}-$ & $1.4 \times 10^{-14}$ & 1.0 & 1-butene & $a, b$ \\
\hline $\mathrm{CH}_{2}=\mathrm{CH}<$ & $3.3 \times 10^{-13}$ & 1.0 & i-butene & $a, b$ \\
\hline$-\mathrm{CH}=\mathrm{CH}-$ & $3.7 \times 10^{-13}$ & 0.5 & 2-butene & $a, b, c$ \\
\hline$-\mathrm{CH}=\mathrm{C}<$ & $9.4 \times 10^{-12}$ & 1.0 & 2-methyl-2-butene & $a, b$ \\
\hline$>\mathrm{C}=\mathrm{C}<$ & $5.7 \times 10^{-11}$ & 0.5 & 2,3-dimethyl-2-butene & $a, b$ \\
\hline \multicolumn{5}{|c|}{ dienes } \\
\hline $\mathrm{CH}_{2}=\mathrm{CH}-\mathrm{CH}=\mathrm{CH}-$ & $1.5 \times 10^{-12}$ & 1.0 & pentadiene & $a, f, g$ \\
\hline$-\mathrm{CH}=\mathrm{CH}-\mathrm{CH}=\mathrm{CH}-$ & $1.6 \times 10^{-11}$ & 0.5 & 2,4-hexadiene & $a, e, f, g$ \\
\hline \multicolumn{5}{|c|}{ unsaturated carbonyls } \\
\hline $\mathrm{CH}_{2}=\mathrm{C}(\mathrm{R}) \mathrm{CO}-$ & $1.4 \times 10^{-15}$ & 1.0 & methacrolein & $b, h$ \\
\hline$-\mathrm{CH}=\mathrm{CHCO}-$ & $8.5 \times 10^{-15}$ & 0.5 & crotonaldehyde & $b, h$ \\
\hline$>\mathrm{CH}=\mathrm{CHCO}-$ & $2.1 \times 10^{-13}$ & 1.0 & & $b, i$ \\
\hline$-\mathrm{CH}=\mathrm{C}(\mathrm{R}) \mathrm{CO}-$ & $1.2 \times 10^{-13}$ & 1.0 & & $b, j$ \\
\hline$>\mathrm{CH}=\mathrm{C}(\mathrm{R}) \mathrm{CO}-$ & $7.7 \times 10^{-13}$ & 0.5 & & $b, k$ \\
\hline
\end{tabular}

${ }^{a}$ rate constants from Atkinson (1997); ${ }^{b}$ branching ratio for $\mathrm{NO}_{3}$ addition at the less substituted carbon; ${ }^{c}$ average value of cis- and trans-2butene; ${ }^{e}$ also used for $>\mathrm{C}=\mathrm{CH}-\mathrm{CH}=\mathrm{CH}-$ and $>\mathrm{C}=\mathrm{CH}-\mathrm{CH}=\mathrm{CH}<$ structures; $^{f}$ if the diene is alkyl substitued or disubstitued in position 2 or 3 , the rate constant is multiplied by a factor 6.8 and 21 , respectively, based on the isoprene/butadiene and 2,3-dimethyl-butadiene/butaniene rate constant ratios; ${ }^{g}$ branching ratio for $\mathrm{NO}_{3}$ addition at the less substituted terminal carbon (i.e. position 1 or 4 ). In the resulting allylic structure, the radical center is located on the most substituted carbon; ${ }^{h}$ see text for references of the rate constants; ${ }^{i}$ rate constant for crotonaldehyde multiplied by the $-\mathrm{CH}=\mathrm{C}</-\mathrm{CH}=\mathrm{CH}-$ rate constant ratio; ${ }^{j}$ average rate for crotonaldehyde and methacrolein multiplied by the $-\mathrm{CH}=\mathrm{C}</ \mathrm{CH}_{2}=\mathrm{CH}<$ and $>\mathrm{C}=\mathrm{C}-/-\mathrm{C}=\mathrm{C}-$ rate constant ratios, respectively; ${ }^{k}$ average rate for crotonaldehyde and methacrolein multiplied by the $-\mathrm{CH}=\mathrm{C}</ \mathrm{CH}_{2}=\mathrm{CH}<$ and $>\mathrm{C}=\mathrm{C}-/-\mathrm{C}=\mathrm{C}-$ rate constant ratio, respectively.

reactions are based on NASA and IUPAC recommendations (Sander et al., 2000; Atkinson et al., 1997) as well as on the recent recommendations of Troe (2001) for the $\mathrm{NO}_{2}+\mathrm{OH} \rightarrow \mathrm{HNO}_{3}$ reaction. Methane oxidation is based on the IUPAC recommendations (Atkinson et al., 1999) and the recommendations of Tyndall et al. (2001) for the methyl peroxy reactions. In the following subsections, we first present the management of radical species within the generator, then reactions associated with non-radical organic species (i.e. reactions with $\mathrm{OH}, \mathrm{NO}_{3}, \mathrm{O}_{3}$, thermal decomposition and photolysis) and finally reactions associated with the organic radicals (i.e. the peroxy, alkoxy and Criegee radicals). The particular case of cyclic molecules is presented last.

\subsection{Radical check in the generator}

To decrease the number of species as well as the stiffness of the set of ordinary differential equations that must ultimately be solved, the steady state approximation is used for highly reactive species having a unique significant reaction pathway. Such species are not considered in the chemical scheme but are directly replaced by their reaction products. For example, the $\mathrm{OH}$ reaction with a paraffin carbon $(\mathrm{RH})$ is written as $\mathrm{RH}+\mathrm{OH}\left(+\mathrm{O}_{2}\right) \rightarrow \mathrm{RO}_{2}+\mathrm{H}_{2} \mathrm{O}$, in which the alkyl radi- cal (R.) first produced by the reaction with $\mathrm{OH}$ is directly replaced by the peroxy radical $\left(\mathrm{RO}_{2}\right)$, its only significant reaction product under tropospheric conditions. Organic radical moieties for which the steady state approximation has been systematically applied are listed in the Table 1 . The only exception to the list presented in the Table 1 is the $\mathrm{HCO}-\mathrm{CO}(\cdot)$ radical which was experimentally found to react both by decomposition and $\mathrm{O}_{2}$ reaction. We used the yields provided by Orlando and Tyndall (2001) for this radical. Note that the reactions listed in the Table 1 for peroxy and alkoxy radicals supersede the rules described in the Sects. 3.7 and 3.8 for these types of radicals.

\section{2 $\mathrm{VOC}+\mathrm{OH}$ reactions}

Rate constants for $\mathrm{H}$ atom abstraction are estimated using the SAR of Kwok and Atkinson (1995), in which we added a group contribution for the hydroperoxide moiety $(-\mathrm{OOH})$. Based on the IUPAC recommendations for $\mathrm{CH}_{3}-\mathrm{OOH}$ (Atkinson et al., 1999), an activation factor of 14 at $298 \mathrm{~K}$ was set for $\mathrm{H}$ abstraction to a carbon bearing the $-\mathrm{OOH}$ functionality and the rate constant for $\mathrm{H}$ abstraction of the $-\mathrm{OOH}$ moiety was set to $1.9 \times 10^{-12} \exp (190 / T)$ molecule $\mathrm{em}^{3} \mathrm{~s}^{-1}$. OH additions 
Table 3. Generic rate constants and branching ratios for alkene+ $\mathrm{O}_{3}$ reactions.

\begin{tabular}{lccl}
\hline Structures & $\begin{array}{c}\text { Rate constant } \\
\text { molecule } \mathrm{cm}^{3} \mathrm{~s}^{-1}\end{array}$ & Branching ratio & Notes \\
\hline & alkenes & & \\
$\mathrm{CH}_{2}=\mathrm{CH}-$ & $1.0 \times 10^{-17}$ & $0.5 / 0.5$ & $a, b$ \\
$\mathrm{CH}_{2}=\mathrm{C}<$ & $1.2 \times 10^{-17}$ & $0.65 / 0.35$ & $a, b$ \\
$-\mathrm{CH}=\mathrm{CH}-$ & $1.1 \times 10^{-16}$ & $0.5 / 0.5$ & $a, b$ \\
$-\mathrm{CH}=\mathrm{C}<$ & $3.5 \times 10^{-16}$ & $0.7 / 0.3$ & $a, b$ \\
$>\mathrm{C}=\mathrm{C}<$ & $1.1 \times 10^{-15}$ & $0.5 / 0.5$ & $c, b$ \\
& dienes & & \\
$-\mathrm{CH}=\mathrm{CH}-\mathrm{CH}=\mathrm{CH}{ }_{2}$ & $3.5 \times 10^{-17}$ & 0.25 for each carbon & $d, e, f$ \\
$>\mathrm{C}=\mathrm{CH}-\mathrm{CH}=\mathrm{CH}{ }_{2}$ & $3.9 \times 10^{-17}$ & 0.25 for each carbon & $d, e, f, g$ \\
$-\mathrm{C}=\mathrm{CH}-\mathrm{CH}=\mathrm{CH}-;>\mathrm{C}=\mathrm{CH}-\mathrm{CH}=\mathrm{CH}-$ & $3.4 \times 10^{-16}$ & 0.25 for each carbon & $h, e, f$ \\
$>\mathrm{C}=\mathrm{CH}-\mathrm{CH}=\mathrm{C}<$ & $3.1 \times 10^{-15}$ & 0.25 for each carbon & $i, e, f$ \\
& unsaturated carbonyls & & \\
$\mathrm{C}=\mathrm{C}-\mathrm{CHO}$ & $2.9 \times 10^{-19}$ & $0.9 / 01$ & $j, l$ \\
$\mathrm{C}=\mathrm{C}-\mathrm{CO}-$ & $5.4 \times 10^{-18}$ & $0.95 / 0.05$ & $k, l$ \\
$\mathrm{HCO}-\mathrm{C}=\mathrm{C}-\mathrm{CHO}$ & $1.6 \times 10^{-18}$ & $0.5 / 0.5$ & $m, e$ \\
$\mathrm{HCO}-\mathrm{C}=\mathrm{C}-\mathrm{CO}-\mathrm{R}$ & $4.8 \times 10^{-18}$ & $0.5 / 0.5$ & $m, e$ \\
$\mathrm{R}-\mathrm{CO}-\mathrm{C}=\mathrm{C}-\mathrm{CO}-\mathrm{R}$ & $3.6 \times 10^{-18}$ & $0.5 / 0.5$ & $m, e$ \\
\hline
\end{tabular}

${ }^{a}$ Rate constants from Carter (2000), average values at $300 \mathrm{~K}$ for various species having the appropriate structure; ${ }^{b}$ branching ratio from Carter (2000). If not equal, the most substituted criegee radical is formed with the highest yield; ${ }^{c}$ rate constant for 2,3-dimethyl-2-butene, Atkinson (1997); ${ }^{d}$ average rate constant for (E) and (Z) 1,3 pentadiene, Atkinson (1997); ${ }^{e}$ no experimental data available for branching ratio. An equal probability is set to each pathway; ${ }^{f}$ rate constant is enhanced by a factor 2 for each alkyl substitution at position 2 or 3 of the diene structure. Enhancement factor based on the isoprene/butadiene and 2,3-dimethyl-butadiene/isoprene rate constant ratio. ${ }^{g}$ rate constant for 1,3 pentadiene enhanced by the rate constant ratio isobutene/propene; ${ }^{h}$ rate constant for 2,4 hexadiene, Atkinson $(1997) ;{ }^{i}$ rate constant for 2,5-dimethyl-2,4-hexadiene, Lewin et al. (2001); ${ }^{j}$ rate constant for acrolein, see text; ${ }^{k}$ rate constant for methyl vinyl ketone, see text; ${ }^{l}$ rate constant enhanced by a factor of 3.9 and 6.0 for each $\mathrm{H}$ substitution by an alkyl group in $\alpha$ or $\beta$ of the carbonyl group, see text; ${ }^{m}$ based on the rate constants provided by Liu et al. (1999).

to $>\mathrm{C}=\mathrm{C}<$ bonds are estimated using the SAR of Peeters et al. (1997), except for alkenes having conjugated carbonyl groups. For these unsaturated carbonyls, the SAR of Kwok and Atkinson (1995) was used. We used a branching ratio of 0.2 and 0.8 for $\mathrm{OH}$ addition to the carbon in $\alpha$ and $\beta$ position relative to the carbonyl group, respectively, based on the yields provided by Tuazon and Atkinson $(1989,1990)$ for methacrolein and methyl-vinyl-ketone. For 1,4 and 1,6 unsaturated dicarbonyls, branching ratio for $\mathrm{OH}$ addition to each olefin carbon was set with an equal probability.

\section{$3.3 \mathrm{VOC}+\mathrm{NO}_{3}$ reactions}

Two VOC $+\mathrm{NO}_{3}$ reaction types are considered: $\mathrm{H}$ abstraction from aldehydes and $\mathrm{NO}_{3}$ addition to alkenes.

Experimental data, including rate constants, are available for aldehydes of low molecular weight. The rate for the butanal $+\mathrm{NO}_{3}$ reaction was used as generic rate for unknown $\mathrm{RCHO}+\mathrm{NO}_{3}$ reactions. The rate constant was set to $1.22 \times 10^{-14}$ molecule ${ }^{-1} \mathrm{~cm}^{3} \mathrm{~s}^{-1}$, based on the data provided by D'Anna et al. (2001). The rate constants for $\mathrm{H}$ - abstraction on conjugated dicarbonyls are estimated using the method of Carter (2000), leading to a rate of $4.8 \times 10^{-16}$ and $2.4 \times 10^{-15}$ molecule ${ }^{-1} \mathrm{~cm}^{3} \mathrm{~s}^{-1}$ for $\mathrm{CHO}-\mathrm{CHO}$ and RCO-CHO, respectively. According to Atkinson (1991), $\mathrm{NO}_{3}$ reaction with acrolein $\left(\mathrm{CH}_{2}=\mathrm{CH}-\mathrm{CHO}\right)$ mainly occurs by $\mathrm{H}$-abstraction at the aldehyde group. The rate constant for $\mathrm{H}$-abstraction in $>\mathrm{C}=\mathrm{C}-\mathrm{CHO}$ structures was set to $2.5 \times 10^{-15}$ molecule ${ }^{-1} \mathrm{~cm}^{3} \mathrm{~s}^{-1}$, based on the rate constant provided by Cabanas et al. (2001) for the acrolein $+\mathrm{NO}_{3}$ reaction.

Reaction rates for $\mathrm{NO}_{3}$ addition to non-conjugated alkenes are evaluated using the method of Jenkin et al. (1997) and Carter (2000). The generic constants as well as the branching ratio used in this study are summarized in Table 2. This method was extended to conjugated alkenes (see Table 2). For conjugated unsaturated carbonyls, reaction rates are available at room temperature for (1) methyl vinyl ketone: $k=1.2 \times 10^{-16}$ (Rudich et al., 1996), (2) methacrolein: $k=3.9 \times 10^{-15}$ (average value of the rate constants provided by Chew et al., 1998; Kwok et al., 1996), and (3) crotonaldehyde: $k=1.1 \times 10^{-14}$ molecule ${ }^{-1} \mathrm{~cm}^{3} \mathrm{~s}^{-1}$ (average value of 
the rate constants provided by Cabanas et al., 2001; Atkinson, 1994). Using a typical nocturnal $\mathrm{NO}_{3}$ concentration of $10^{9}$ molecule $\mathrm{cm}^{-3}$, the lifetime of methyl vinyl ketone with respect to $\mathrm{NO}_{3}$ reaction is estimated to be of about 100 days, i.e. well above the corresponding lifetime due to $\mathrm{OH}$ removal $(\approx 10 \mathrm{~h})$. We therefore did not considered the $\mathrm{NO}_{3}$ addition to $\mathrm{CH}_{2}=\mathrm{CH}-\mathrm{CO}-$ structures. Note that this very slow reaction rate is in agreement with the expected minor contribution of $\mathrm{NO}_{3}$ addition to the $\mathrm{C}=\mathrm{C}$ bond pointed above for acrolein. Furthermore, assuming that $\mathrm{H}$ atom abstraction from the $-\mathrm{CHO}$ group contributes $2.5 \times 10^{-15}$ to the total rate constant (see above), the rate for $\mathrm{NO}_{3}$ addition to $\mathrm{C}=\mathrm{C}$ bond can be estimated to $1.4 \times 10^{-15}$ and $8.5 \times 10^{-15}$ molecule ${ }^{-1} \mathrm{~cm}^{3} \mathrm{~s}^{-1}$ for methacrolein and crotonaldehyde, respectively. These rate constants were (1) directly used as generic constants for $\mathrm{CH}_{2}=\mathrm{C}(\mathrm{R})-\mathrm{CO}-$ and $\mathrm{R}-\mathrm{CH}=\mathrm{CH}-\mathrm{CO}-$ structures, and (2) combined with the generic constants for $\mathrm{NO}_{3}$ addition to simple alkenes to evaluate $\mathrm{NO}_{3}$ addition rates for more substituted structures. Rules used for this last evaluation are given in Table 2. Finally, no data are available to our knowledge concerning the reaction rates of $\mathrm{NO}_{3}$ reaction with 1,4 unsaturated dicarbonyls. The data listed Table 2 suggest however that the substitution of an alkyl group with a carbonyl group typically decreases the rate constant by 2 orders of magnitude. For 1,4 unsaturated dicarbonyl, we therefore scaled by a factor of $10^{-2}$ the generic constant provided in Table 2 for unsaturated carbonyls. Although crude, the evaluation suggests very low rate constants for the $\mathrm{NO}_{3}$ reaction with 1,4 unsaturated dicarbonyl and these reactions should not be a significant loss process under tropospheric conditions.

\section{4 $\mathrm{VOC}+\mathrm{O}_{3}$ reactions}

Rate constant estimations for the reaction of non-conjugated alkenes with $\mathrm{O}_{3}$ are based on the method of Jenkin et al. (1997) and Carter (2000). Generic constants as well as the branching ratios for carbonyl and Criegee radical formation at both side of the $>\mathrm{C}=\mathrm{C}<$ bond are given in the Table 3. This method was extended to conjugated dienes (see Table 3). Evaluations for unsaturated carbonyl were based on the following rate constants at room temperature (in molecule $\mathrm{e}^{-1} \mathrm{~cm}^{3} \mathrm{~s}^{-1}$ units):

- acrolein: $k=2.9 \times 10^{-19}$ (Atkinson, 1994);

- methyl vinyl ketone: $k=5.4 \times 10^{-18}$ (Neeb et al., 1998)

- methacrolein: $k=1.1 \times 10^{-18}$ (Atkinson, 1994)

- crotonaldehyde: $k=1.7 \times 10^{-18}$ (Grosjean and Grosjean, 1998)

Rates for acrolein and methyl vinyl ketone were used as generic constants for unsaturated aldehydes and ketones, respectively. Contribution of alkyl groups in $\alpha$ and $\beta$ positions relative to the carbonyl were taken into account using an enhancement factor of 3.9 and 6.0, respectively, based on the rate constant ratio of methacrolein and crotonaldehyde with respect to acrolein. Rate constants provided by Liu et al. (1999) were used as generic values for 1,4 unsaturated dicarbonyls (see Table 3). $\mathrm{O}_{3}$ reactions with 1,6 di-unsaturated dicarbonyls are of the order of $10^{-19}$ molecule ${ }^{-1} \mathrm{~cm}^{3} \mathrm{~s}^{-1}$ Klotz et al. (1995). Using a typical $\mathrm{O}_{3}$ concentration of $10^{12}$ molecule $\mathrm{cm}^{-3}$, the lifetime for 1,6 diunsaturated dicarbonyls with respect to $\mathrm{O}_{3}$ reaction is estimated to be about $10^{2}$ days, i.e. well above the corresponding lifetime due to $\mathrm{OH}$ removal $(\approx 10 \mathrm{~h})$. The reaction of $\mathrm{O}_{3}$ with 1,6 diunsaturated dicarbonyls was therefore not considered.

\subsection{VOC photolysis}

Photolytic reactions are considered for 3 types of chromophores: carbonyl, hydroperoxide, and nitrate. The cross sections and quantum yields of 54 species are tabulated in the generator (see list in Laval-Szopa, 2003). Some of these photolysis parameters are used to directly assign the photolytic frequencies to a given chemical structure. The reference compounds used to assign rate constants to structures are given in the Table 4. For multifunctional species, each chromophore leading to photolysis is treated independently, except conjugated carbonyls.

\subsection{Thermal decomposition}

Thermal decomposition is only considered for PAN like species: $\quad \mathrm{RC}(\mathrm{O}) \mathrm{OONO}_{2} \rightarrow \mathrm{RC}(\mathrm{O})(\mathrm{OO} \cdot)+\mathrm{NO}_{2}$. Rate constant recommended by Tyndall et al. (2001) for $\mathrm{CH}_{3} \mathrm{C}(\mathrm{O}) \mathrm{OONO}_{2}$ is used for all $\mathrm{C}_{2}$ compounds. For longer carbon chain $\left(\mathrm{C}_{>2}\right)$, the rate constant is set to the high pressure limit recommended by Atkinson et al. (1999) for $\mathrm{C}_{2} \mathrm{H}_{5} \mathrm{C}(\mathrm{O}) \mathrm{OONO}_{2}$ : $k=2.0 \times 10^{15} \exp (-12800 / T)$ molecule ${ }^{-1} \mathrm{~cm}^{3} \mathrm{~s}^{-1}$.

\subsection{Peroxy radical reactions}

The following reactions of organic peroxy radicals with $\mathrm{NO}$, $\mathrm{NO}_{3}, \mathrm{HO}_{2}$ and other $\mathrm{RO}_{2}$ are considered in the generator:

$$
\begin{aligned}
\mathrm{R}(\mathrm{OO} \cdot)+\mathrm{NO} & \rightarrow \mathrm{R}(\mathrm{O} \cdot)+\mathrm{NO}_{2} \\
& \rightarrow \mathrm{R}\left(\mathrm{ONO}_{2}\right) \\
\mathrm{RC}(\mathrm{O})(\mathrm{OO} \cdot)+\mathrm{NO}_{2} & \rightarrow \mathrm{RC}(\mathrm{O})\left(\mathrm{OONO}_{2}\right) \\
\mathrm{R}(\mathrm{OO} \cdot)+\mathrm{NO}_{3} & \rightarrow \mathrm{R}(\mathrm{O} \cdot)+\mathrm{NO}_{2}+\mathrm{O}_{2} \\
\mathrm{R}(\mathrm{OO} \cdot)+\mathrm{HO}_{2} & \rightarrow \mathrm{R}(\mathrm{OOH})+\mathrm{O}_{2} \\
\mathrm{R}(\mathrm{OO} \cdot)+\mathrm{HO}_{2} & \rightarrow \mathrm{R}(\mathrm{OH})+\mathrm{O}_{3} \\
\mathrm{R}(\mathrm{OO} \cdot)+\mathrm{R}^{\prime}(\mathrm{OO} \cdot) & \rightarrow \mathrm{R}(\mathrm{O} \cdot)+\mathrm{R}^{\prime}(\mathrm{O} \cdot)+\mathrm{O}_{2} \\
& \rightarrow \mathrm{R}(=\mathrm{O})+\mathrm{R}^{\prime}(\mathrm{OH})+\mathrm{O}_{2} \\
& \rightarrow \mathrm{R}(\mathrm{OH})+\mathrm{R}^{\prime}(=\mathrm{O})+\mathrm{O}_{2}
\end{aligned}
$$

Note that the Reaction (R2) is only considered for alkyl peroxy radicals while Reactions (R3) and (R6) are considered 
Table 4. Reference compounds used to assign photolysis parameters to various chemical structures.

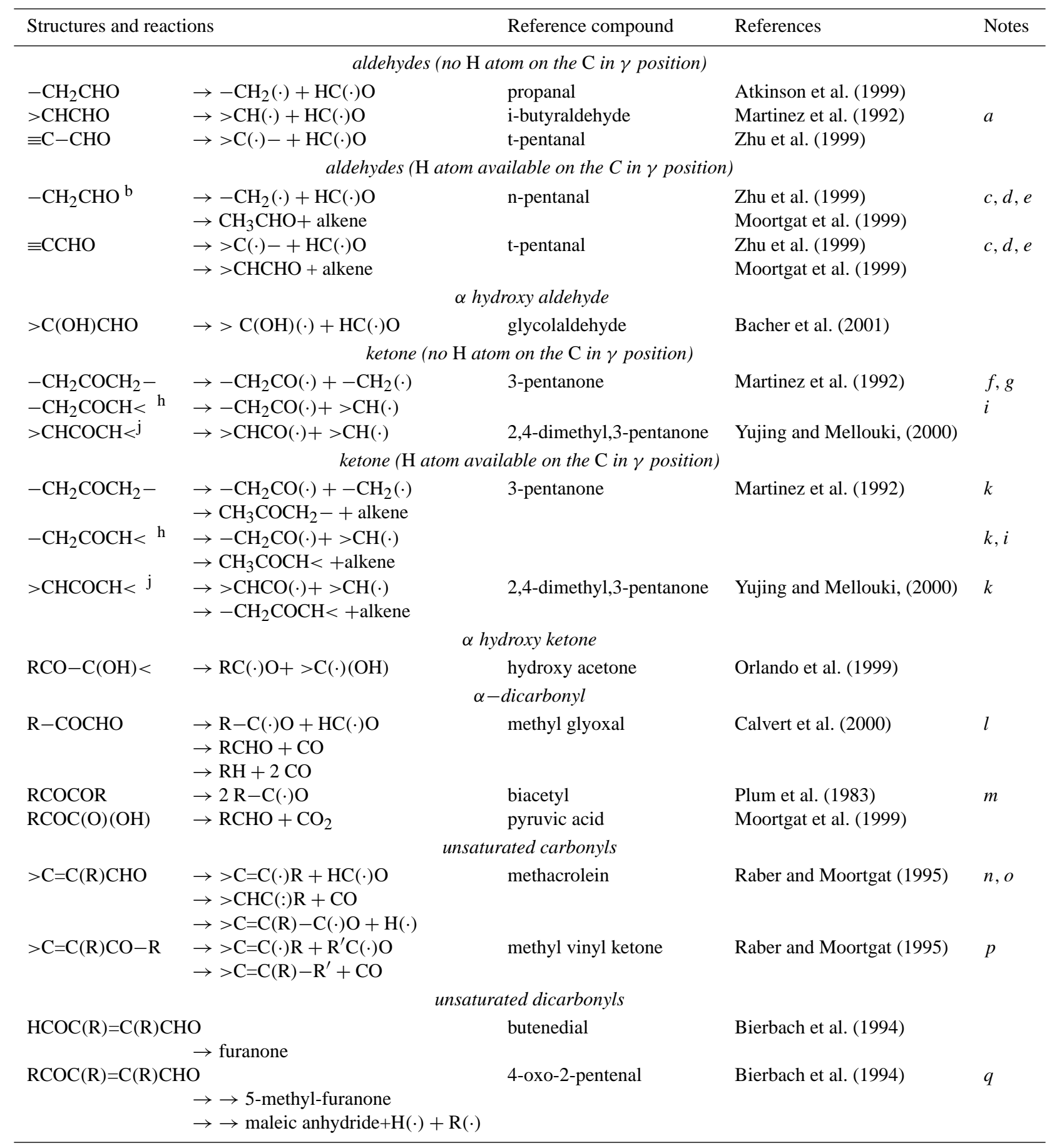

for acyl peroxy radicals only. We first briefly present below the rate constant selected for alkyl peroxy radicals, then for acyl peroxy radicals.

Rate constants for alkyl peroxy reactions with $\mathrm{NO}$ were set to $2.7 \times 10^{-12} \exp (360 / T)$ molecule ${ }^{-1} \mathrm{~cm}^{3} \mathrm{~s}^{-1}$, based on Atkinson (1997) recommendations. Yields for organic nitrate and alkoxy radical formation are estimated using the SAR of Carter (2000), and depend on the peroxy class, the presence of polar functional groups (e.g. hydroxyl, carbonyl, nitrate) and the length of the carbon chain. The reaction rate recommended by Atkinson et al. (1999) for the $\mathrm{C}_{2} \mathrm{H}_{5} \mathrm{O}_{2}+\mathrm{NO}_{3}$ reaction (i.e. $2.5 \times 10^{-12}$ molecule ${ }^{-1} \mathrm{~cm}^{3} \mathrm{~s}^{-1}$ ) was used as a generic constant for the $\mathrm{RO}_{2}+\mathrm{NO}_{3}$ reactions. Rate constants for the 
Table 4. Continued.

\begin{tabular}{|c|c|c|c|c|}
\hline Structures and react & ions & Reference compound & References & Notes \\
\hline \multicolumn{5}{|c|}{ unsaturated dicarbonyls (continued) } \\
\hline \multicolumn{2}{|c|}{$\mathrm{RCOC}(\mathrm{R})=\mathrm{C}(\mathrm{R}) \mathrm{CHO}$} & 3-hexene-2,5-dione & Bierbach et al. (1994) & $q$ \\
\hline \multicolumn{5}{|c|}{$\rightarrow \rightarrow \mathrm{RCOC}(\mathrm{R})=\mathrm{C}(\mathrm{R}) \mathrm{C}(\cdot) \mathrm{O}+\mathrm{H}(\cdot)$} \\
\hline \multicolumn{5}{|c|}{$\begin{aligned}-\mathrm{COC}(\mathrm{R})=\mathrm{C}(\mathrm{R}) \mathrm{C}(\mathrm{R}) & =\mathrm{C}(\mathrm{R}) \mathrm{CHO} \\
& \rightarrow \rightarrow-\mathrm{COC}(\mathrm{R})=\mathrm{C}(\mathrm{R}) \mathrm{C}(\mathrm{R})=\mathrm{C}(\cdot)(\mathrm{R})+\mathrm{HC}(\cdot) \mathrm{O} \\
& \rightarrow \rightarrow-\mathrm{COC}(\mathrm{R})=\mathrm{C}(\mathrm{R}) \mathrm{C}(\mathrm{R})=\mathrm{C}(\mathrm{R}) \mathrm{C}(\cdot) \mathrm{O}+\mathrm{H}(\cdot)\end{aligned}$} \\
\hline \multicolumn{5}{|c|}{ hydroperoxide } \\
\hline $\mathrm{R}(\mathrm{OOH})$ & $\rightarrow \mathrm{R}(\mathrm{O} \cdot)+\mathrm{HO}$ & methyl hydroperoxide & Atkinson et al. (1999) & \\
\hline \multicolumn{5}{|c|}{ nitrate } \\
\hline$-\mathrm{CH}_{2}\left(\mathrm{ONO}_{2}\right)$ & $\rightarrow-\mathrm{CH}_{2}(\cdot)+\mathrm{NO}_{2}$ & 1-pentylnitrate & Zhu and Kellis (1997) & \\
\hline$>\mathrm{CH}\left(\mathrm{ONO}_{2}\right)$ & $\rightarrow>\mathrm{CH}(\cdot)+\mathrm{NO}_{2}$ & 2-butylnitrate & Atkinson et al. (1999) & \\
\hline$>\mathrm{C}\left(\mathrm{ONO}_{2}\right)-$ & $\rightarrow>\mathrm{C}(\cdot)-+\mathrm{NO}_{2}$ & t-butylnitrate & Roberts and Fajer (1989) & \\
\hline $\mathrm{R}-\mathrm{C}(\mathrm{O})\left(\mathrm{OONO}_{2}\right)$ & $\rightarrow \mathrm{R}-\mathrm{C}(\mathrm{O})(\mathrm{OO} \cdot)+\mathrm{NO}_{2}$ & peroxy acetyl nitrate & Atkinson et al. (1999) & \\
\hline
\end{tabular}

${ }^{a}$ quantum yields are from Desai et al. (1986); ${ }^{b}$ this structure was also used for di substituted aldehydes on the $\alpha$ carbon; ${ }^{c}$ quantum yields of the radical channel are from Zhu et al. (1999), quantum yield for the Norrish type II reaction are from Moortgat et al. (1999) for n-pentanal; $d$ enols $\left(>\mathrm{C}=\mathrm{C}(\mathrm{OH})-\right.$ ) produced by the Norrish type II reaction pathways are assumed to rearrange to the carbonyl form $(>\mathrm{CH}-\mathrm{CO}-)^{e}{ }^{e}$ the more labile $\mathrm{H}$ is used to perform the Norrish II reaction if distinct $\mathrm{H}$ are available on the $\gamma$ carbon; ${ }^{f}$ dissociation occurs at the weakest $\mathrm{CO}-\mathrm{C}$ bond. Bond energies are estimated using the Benson method (Benson, 1976); ${ }^{g}$ total quantum yield based on 2-butanone values from Raber and Moortgat (1995); ${ }^{h}$ this reaction is also used for $-\mathrm{CH}_{2}-\mathrm{CO}-\mathrm{C} \equiv$ structures; ${ }^{i}$ average value of 3-pentanone and 2,4-dimethyl3-pentanone; ${ }^{j}$ this reaction is also used for $>\mathrm{CH}-\mathrm{CO}-\mathrm{C} \equiv$ and $\equiv \mathrm{C}-\mathrm{CO}-\mathrm{C} \equiv$ structures; $^{k}$ branching ratios for the molecular and radical channel set to 0.7 and 0.3 , respectively. These ratios are based on an absolute quantum yield of 0.1 estimated by Carter (2000) for methyl isopropyl ketone; ${ }^{l}$ quantum yields from Koch and Moortgat (1998) and Raber and Moortgat (1995); ${ }^{m}$ Quantum yield from Carter (2000); ${ }^{n}$ quantum yield from Magneron et al. (1999); ${ }^{o}$ the carbene radical is expected to add $\mathrm{O}_{2}$ to form a criegee like radical; ${ }^{p}$ quantum yield from Carter (1996); ${ }^{q}$ both channels are set with an equal probability.

$\mathrm{RO}_{2}+\mathrm{HO}_{2}$ reactions are evaluated using the SAR of Boyd et al. (2003) and depend on the chain length. For these reactions, the temperature dependencies of the rate constants show that Arrhenius activation energy factors are in the range of 1000-1500 K (Lesclaux, 1997). We therefore used an average activation energy factor of $1250 \mathrm{~K}$ and modified the SAR of Boyd et al. (2003) accordingly. The counter species method of Madronich and Calvert (1990) was used to parameterize the $\mathrm{RO}_{2}+\mathrm{RO}_{2}$ reactions. However, while Madronich and Calvert (1990) treated the counter species analogously to all other species (i.e. solved by the integration of differential equations), here we simply compute counter concentrations at each time step by summing the concentrations of the various peroxy radicals. Ten reactivity classes of $\mathrm{RO}_{2}$ are considered in the generator, based on the review of Lesclaux (1997). These classes are given in the Table 5 as well as their corresponding kinetic parameters for the self-reactions (i.e. the reaction between 2 peroxy belonging to the same class). Rate constant for cross-reaction (i.e. the reaction between 2 peroxy belonging to distinct classes) are evaluated as by Madronich and Calvert (1990). The only exception is for the cross reactions of acyl and alkyl peroxy radicals, for which the rate constant was set to $1.0 \times 10^{-11}$ molecule ${ }^{-1} \mathrm{~cm}^{3} \mathrm{~s}^{-1}$, independently of the alkyl peroxy class (Villenave et al., 1998).
Rates for $\mathrm{CH}_{3} \mathrm{C}(\mathrm{O})(\mathrm{OO} \cdot)$ reaction with $\mathrm{NO}, \mathrm{HO}_{2}, \mathrm{NO}_{3}$ and $\mathrm{RO}_{2}$ were used as generic constants for the corresponding acyl peroxy radical reactions. Rate constants were set to (1) $8.1 \times 10^{-12} \exp (270 / T)$ for the reaction with NO (Tyndall et al., 2001), (2) $5.0 \times 10^{-12}$ for the reaction with $\mathrm{NO}_{3}$ (Canosa-Mas et al., 1996) and (3) $1.4 \times 10^{-13} \exp (925 / T)$ molecule $\mathrm{cm}^{-1} \mathrm{~s}^{-1}$ for the reaction with $\mathrm{HO}_{2}$ (Tomas et al., 2001). A branching ratio of 0.8 and 0.2 was set for the Reactions (R5) and (R6), respectively, based on Tomas et al. (2001). The $\mathrm{CH}_{3} \mathrm{C}(\mathrm{O})(\mathrm{OO} \cdot)+\mathrm{NO}_{2}$ reaction is in the fall off regime. The rate constants recommended by Tyndall et al. (2001) for this reaction was directly used for the corresponding reactions of $\mathrm{C}_{2}$ species and the high pressure rate constant was assigned for $\mathrm{C}_{>2}$ species, according to the recommendations of Atkinson (1994).

\subsection{Alkoxy radical reactions}

Alkoxy radicals undergo three reaction types under tropospheric conditions, namely reaction with $\mathrm{O}_{2}$, beta scission decomposition and 1,5-H-shift isomerization:

$$
\begin{aligned}
>\mathrm{CH}(\mathrm{O} \cdot)+\mathrm{O}_{2} & \rightarrow>\mathrm{C}(=\mathrm{O})+\mathrm{HO}_{2} \\
>\mathrm{C}(\mathrm{O} \cdot)-\mathrm{R} & \rightarrow>\mathrm{C}(=\mathrm{O})+\mathrm{R}(\cdot) \\
>\mathrm{CH}-(\mathrm{C})_{2}-\mathrm{C}(\mathrm{O} \cdot)< & \rightarrow>\mathrm{C}(\cdot)-(\mathrm{C})_{2}-\mathrm{C}(\mathrm{OH})<
\end{aligned}
$$


Table 5. Rate constants at $298 \mathrm{~K}$, Arrhenius parameters and radical channel branching ratios $\alpha$ for peroxy radical self reactions.

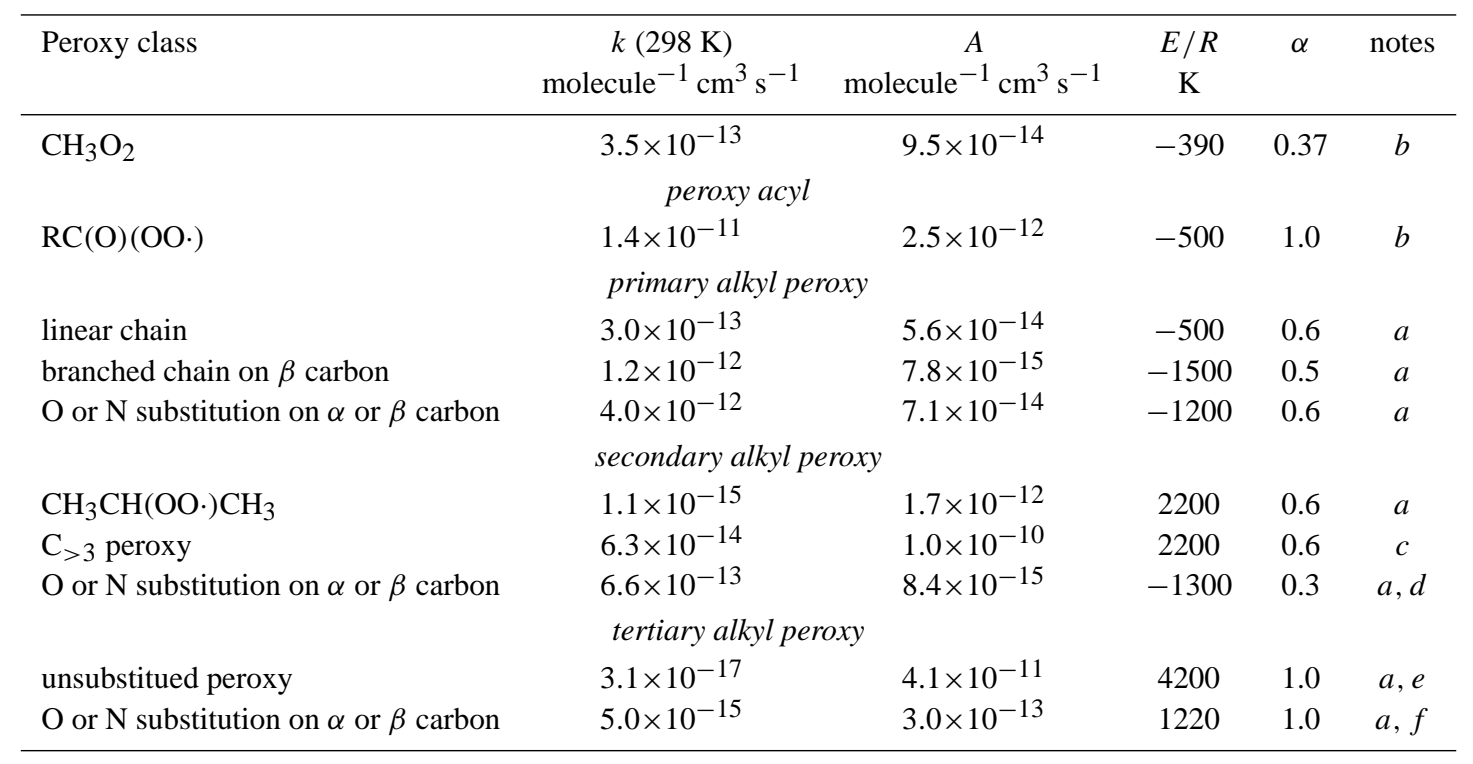

${ }^{a}$ Kinetic and mechanistic parameters from Lesclaux (1997); ${ }^{b}$ kinetic and mechanistic parameters from Tyndall et al. (2001); ${ }^{c}$ rate constant based on Boyd et al. (1999) for the reaction of $\mathrm{C}_{5} \mathrm{H}_{11} \mathrm{O}_{2}$ and $\mathrm{C}_{10} \mathrm{H}_{21} \mathrm{O}_{2}$ and using the activation energy and the branching ratio for ipropyl peroxy radical.; ${ }^{d}$ based on kinetic and mechanistic parameters for $\mathrm{CH}_{3} \mathrm{CH}(\mathrm{OH}) \mathrm{CH}(\mathrm{OO} \cdot) \mathrm{CH}_{3} ;{ }^{e}$ based on kinetic and mechanistic parameters for $\left(\mathrm{CH}_{3}\right)_{3} \mathrm{C}(\mathrm{OO} \cdot) ;{ }^{f}$ based on kinetic and mechanistic parameters for $\mathrm{CH}_{3} \mathrm{C}\left(\mathrm{CH}_{3}\right)(\mathrm{OH}) \mathrm{C}(\mathrm{OO} \cdot)\left(\mathrm{CH}_{3}\right) \mathrm{CH}_{3}$.

Table 6. Arrhenius parameters for alkoxy radical reactions (adapted from Carter, 2000).

\begin{tabular}{|c|c|c|c|}
\hline Structures and reactions & $A^{a}$ & $E a\left(\mathrm{kcal} \mathrm{mol}^{-1}\right)$ & Notes \\
\hline \multicolumn{4}{|c|}{ Reaction with $\mathrm{O}_{2}$} \\
\hline$-\mathrm{CH}_{2}(\mathrm{O} \cdot)+\mathrm{O}_{2} \rightarrow-\mathrm{CHO}+\mathrm{HO}_{2}$ & $6.0 \times 10^{-14}$ & $6.96+0.183 \times \Delta_{r} \mathrm{H}$ & $b, c$ \\
\hline$>\mathrm{CH}(\mathrm{O} \cdot)+\mathrm{O}_{2} \rightarrow>\mathrm{CO}+\mathrm{HO}_{2}$ & $1.5 \times 10^{-14}$ & $6.96+0.183 \times \Delta_{r} \mathrm{H}$ & $d$ \\
\hline \multicolumn{4}{|c|}{ 1,5 H-shift isomerization } \\
\hline $\mathrm{CH}_{3}-\mathrm{C}_{\mathrm{X}}-\mathrm{C}-\mathrm{C}(\mathrm{O} \cdot)<\rightarrow \mathrm{CH}_{2}(\cdot)-\mathrm{C}_{\mathrm{X}}-\mathrm{C}-\mathrm{C}(\mathrm{OH})<$ & $2.4 \times 10^{11}$ & $8.49+3.72 \times \ln \left(F_{X}\right)$ & $d, e$ \\
\hline $\mathrm{Y}-\mathrm{CH}_{2}-\mathrm{C}_{\mathrm{X}}-\mathrm{C}-\mathrm{C}(\mathrm{O} \cdot)<\rightarrow \mathrm{Y}-\mathrm{CH}(\cdot)-\mathrm{C}_{\mathrm{x}}-\mathrm{C}-\mathrm{C}(\mathrm{OH})<$ & $1.6 \times 10^{11}$ & $6.33+3.72 \times \ln \left(F_{X} F_{Y}\right)$ & $d, e$ \\
\hline $\mathrm{Y}-\mathrm{CH}(\mathrm{Z})-\mathrm{C}_{\mathrm{X}}-\mathrm{C}-\mathrm{C}(\mathrm{O} \cdot)<\rightarrow \mathrm{Y}-\mathrm{C}(\cdot)(\mathrm{Z})-\mathrm{C}_{\mathrm{X}}-\mathrm{C}-\mathrm{C}(\mathrm{OH})<$ & $8.0 \times 10^{10}$ & $5.51+3.72 \times \ln \left(F_{X} F_{Y} F_{Z}\right)$ & $d, e$ \\
\hline $\mathrm{CHO}-\mathrm{C}_{\mathrm{x}}-\mathrm{C}-\mathrm{C}(\mathrm{O} \cdot)<\rightarrow \mathrm{C}(\cdot) \mathrm{O}-\mathrm{C}_{\mathrm{x}}-\mathrm{C}-\mathrm{C}(\mathrm{OH})<$ & $8.0 \times 10^{10}$ & $5.75+3.72 \times \ln \left(F_{X}\right)$ & $d, e$ \\
\hline \multicolumn{4}{|c|}{ decomposition } \\
\hline$>\mathrm{C}(\mathrm{O} \cdot)-\mathrm{R} \rightarrow>\mathrm{CO}+\mathrm{R}(\cdot)$ & $2.4 \times 10^{14}$ & $E a a+0.44 \times \Delta_{r} \mathrm{H}$ & $c, f$ \\
\hline \multicolumn{4}{|c|}{ ester rearrangement } \\
\hline $\mathrm{RC}(\mathrm{O})-\mathrm{O}-\mathrm{CH}(\mathrm{O} \cdot)-\mathrm{R} \rightarrow \mathrm{RC}(\mathrm{O})(\mathrm{OH})+\mathrm{RC}(\cdot) \mathrm{O}$ & $8.0 \times 10^{10}$ & $10.23+0.35 \times \Delta_{r} \mathrm{H}$ & $c$ \\
\hline
\end{tabular}

${ }^{a}$ A parameters are given in the [molecule $-\mathrm{cm}-\mathrm{s}$ ] unit system; ${ }^{b} E a$ is set to a minimum of $0.4 \mathrm{kcal} \mathrm{mol}^{-1}$ if the expression leads to lower values; ${ }^{c}$ the heats of reaction are evaluated in the generator using the group contribution of Benson (1976) for formation heats estimation, with additional groups taken in Carter (2000) and Laval-Szopa (2003); ${ }^{d} F_{I}$ factors are the neighbouring group activation parameters used for $\mathrm{H}$ abstraction by $\mathrm{OH}$ at $298 \mathrm{~K}$ in the SAR of Kwok and Atkinson (1995); ${ }^{e}$ Activation energy for isomerization involving -O-, - COor $-\mathrm{O}-\mathrm{CO}-$ groups in the cyclic transition state are increased by an additional $3.5 \mathrm{kcal} \mathrm{mol}^{-1} ; f$ the Eaa parameter is a function of the leaving group. Numerical values for the various groups can be found in Carter (2000).

Absolute rate constants for alkoxy radical reactions are very sparse and most data available concern branching ratios only. Note that alkoxy radicals are very reactive species (lifetime lesser than $\approx 10^{-5} \mathrm{~s}$ ) and their concentrations do not directly contribute to the organic carbon or radical budgets to any significant extent. The branching ratio is therefore the critical 
Table 7. Branching ratios for the reactions of excited Criegee radicals (adapted from Carter (2000).

\begin{tabular}{|c|c|c|}
\hline Structures and reactions & Yields & Notes \\
\hline $\begin{aligned} \mathrm{HCH}(\cdot) & (\mathrm{OO} \cdot) \\
\rightarrow & \mathrm{HCH}(\cdot)(\mathrm{OO} \cdot)(\text { stab. }) \\
\rightarrow & \mathrm{HC}(\cdot) \mathrm{O}+\mathrm{OH} \\
\rightarrow & \mathrm{CO}_{2}+\mathrm{H}_{2} \\
\rightarrow & \mathrm{CO}+\mathrm{H}_{2} \mathrm{O} \\
& \quad \text { External Criegee radicals }\end{aligned}$ & $\begin{array}{l}0.37 \\
0.12 \\
0.13 \\
0.38\end{array}$ & $a$ \\
\hline $\begin{aligned} \mathrm{CH}_{3} \mathrm{CH}(\cdot)(\mathrm{OO} \cdot) & \\
& \rightarrow \mathrm{CH}_{3} \mathrm{CH}(\cdot)(\mathrm{OO} \cdot)(\text { stab. }) \\
& \rightarrow \mathrm{CH}_{3}(\cdot)+\mathrm{CO}+\mathrm{OH} \\
& \rightarrow \mathrm{CH}_{4}+\mathrm{CO}_{2}\end{aligned}$ & $\begin{array}{l}0.34 \\
0.52 \\
0.14\end{array}$ & $a$ \\
\hline $\begin{array}{rl}\mathrm{RC}_{>2} & \mathrm{CH}(\cdot)(\mathrm{OO} \cdot) \\
& \rightarrow \mathrm{CH}_{3} \mathrm{CH}(\cdot)(\mathrm{OO} \cdot)(\text { stab. }) \\
& \rightarrow \mathrm{R}(\cdot)+\mathrm{CO}+\mathrm{OH}\end{array}$ & $\begin{array}{c}1-\mathrm{Y} \\
\mathrm{Y}\end{array}$ & $a, b$ \\
\hline $\begin{array}{l}\mathrm{R}-\mathrm{CO}-\mathrm{CH}(\cdot)(\mathrm{OO} \cdot) \\
\quad \rightarrow \mathrm{R}-\mathrm{C}(\cdot)(\mathrm{OO} \cdot)-\mathrm{CHO} \\
>\mathrm{C}=\mathrm{C}(\mathrm{R})-\mathrm{CH}(\cdot)(\mathrm{OO} \cdot)\end{array}$ & & \\
\hline $\begin{aligned} \rightarrow>\mathrm{C}=\mathrm{C}(\mathrm{R})-\mathrm{CH}(\cdot)(\mathrm{OO} \cdot)(\mathrm{stab}) \\
\rightarrow>\mathrm{C}=\mathrm{CH}(\mathrm{R})+\mathrm{CO}_{2} \\
\text { Internal Criegee radicals }\end{aligned}$ & $\begin{array}{l}0.75 \\
0.25\end{array}$ & \\
\hline $\begin{array}{l}>\mathrm{CH}-\mathrm{C}(\cdot)(\mathrm{OO} \cdot)-\mathrm{R} \\
\quad \rightarrow>\mathrm{C}(\cdot)-\mathrm{C}(\mathrm{O})-\mathrm{R}+\mathrm{OH}\end{array}$ & 1 & $c, d$ \\
\hline
\end{tabular}

a External stabilized biradicals are assumed to be converted into the corresponding carboxylic acid; ${ }^{b}$ branching ratio for the $\mathrm{OH}$ channel decreases with the chain length. Yields are set to $0.46,0.36$, 0.24, 0.16, 0.08 and 0.0 for $\mathrm{C}_{2}, \mathrm{C}_{3}, \mathrm{C}_{4}, \mathrm{C}_{5}, \mathrm{C}_{6}$ and $\mathrm{C}_{>7}$ biradical, respectively, based on Paulson et al. (1999); ${ }^{c}$ if the 2 substituents on the biradical have abstractable $\mathrm{H}$, branching ratio is set to the rate constant ratio of the corresponding $\mathrm{H}$ abstraction with $\mathrm{OH} ;{ }^{d}$ if no abstractable $\mathrm{H}$ is available, then branching ratio is set to $0.9 / 0.1$ for stabilization by collision and decomposition to $2 \mathrm{R}(\cdot)+\mathrm{CO}_{2}$, respectively.

parameters that must accurately be evaluated for the development of atmospheric chemical schemes. Structure/activity relationships for alkoxy reactions were recently developed by Carter (2000) for the purpose of chemical scheme generations and provide a consistent set of rules for branching ratio evaluations. The expressions recommended by Carter (2000) were implemented in the generator and systematically used to evaluate the rate constants associated to the alkoxy reactions. These expressions are summarized in the Table 6 .

\subsection{Criegee radical reactions}

Energy rich Criegee biradicals (i.e. $>\mathrm{C}(\cdot)(\mathrm{OO} \cdot)$ structures) are produced by the $\mathrm{O}_{3}+$ alkene reactions. These excited biradicals can either be stabilized by collision or undergo various unimolecular decompositions, leading to the production of radicals (in particular $\mathrm{OH}$ ) or "stable" species. Branching ratios depend (1) on the identity of the substituents at-
Table 8. Representative $\mathrm{C}_{7}$ secondary organics contributing to the organic budget during heptane oxidation.

\begin{tabular}{|c|}
\hline 1 functional group \\
\hline $\begin{array}{l}\mathrm{CH}_{3} \mathrm{CH}_{2} \mathrm{CH}_{2} \mathrm{CH}_{2} \mathrm{CH}\left(\mathrm{ONO}_{2}\right) \mathrm{CH}_{2} \mathrm{CH}_{3} \\
\mathrm{CH}_{3} \mathrm{CH}_{2} \mathrm{CH}_{2} \mathrm{CH}_{2} \mathrm{COCH} \mathrm{CH}_{3} \\
\mathrm{CH}_{3} \mathrm{CH}_{2} \mathrm{CH}_{2} \mathrm{CH}_{2} \mathrm{CH}(\mathrm{OOH}) \mathrm{CH}_{2} \mathrm{CH}_{3} \\
\text { 2 functional group }\end{array}$ \\
\hline \begin{tabular}{l}
$\mathrm{CH}_{3} \mathrm{CH}_{2} \mathrm{COCH}_{2} \mathrm{CH}_{2} \mathrm{COCH}_{3}$ \\
$\mathrm{CH}_{3} \mathrm{CH}(\mathrm{OH}) \mathrm{CH}_{2} \mathrm{CH}_{2} \mathrm{COCH}_{2} \mathrm{CH}_{3}$ \\
$\mathrm{CH}_{3} \mathrm{CH}_{2} \mathrm{COCH} \mathrm{CH}_{2} \mathrm{CH}\left(\mathrm{ONO}_{2}\right) \mathrm{CH}_{3}$ \\
\multicolumn{2}{c}{3 functional group }
\end{tabular} \\
\hline $\begin{array}{c}\mathrm{CH}_{3} \mathrm{CH}_{2} \mathrm{COCH}_{2} \mathrm{CH}\left(\mathrm{ONO}_{2}\right) \mathrm{CH}(\mathrm{OH}) \mathrm{CH}_{3} \\
\mathrm{CH}_{2}(\mathrm{OH}) \mathrm{CH}_{2} \mathrm{CH}_{2} \mathrm{COCH}_{2} \mathrm{COCH}_{3} \\
\mathrm{CH}_{3} \mathrm{CH}(\mathrm{OH}) \mathrm{COCH}_{2} \mathrm{COCH}_{2} \mathrm{CH}_{3} \\
\mathrm{CH}_{3} \mathrm{CH}_{2} \mathrm{COCH}\left(\mathrm{ONO}_{2}\right) \mathrm{CH}_{2} \mathrm{COCH}_{3} \\
4 \text { functional group }\end{array}$ \\
\hline $\begin{array}{l}\mathrm{CH}_{2}(\mathrm{OH}) \mathrm{COCH}_{2} \mathrm{COCH}_{2} \mathrm{COCH}_{3} \\
\mathrm{CH}_{3} \mathrm{COCH} \mathrm{COCH}_{2} \mathrm{CH}\left(\mathrm{ONO}_{2}\right) \mathrm{CH}_{2}(\mathrm{OH}) \\
\mathrm{CH}_{2}(\mathrm{OH}) \mathrm{CH}_{2} \mathrm{CH}\left(\mathrm{ONO}_{2}\right) \mathrm{COCH}_{2} \mathrm{COCH}_{3} \\
\mathrm{CH}_{3} \mathrm{COCH} \mathrm{CH}_{2} \mathrm{CH}\left(\mathrm{ONO}_{2}\right) \mathrm{CH}(\mathrm{OH}) \mathrm{CH}\left(\mathrm{ONO}_{2}\right) \mathrm{CH}_{3}\end{array}$ \\
\hline
\end{tabular}

tached to the biradicals (e.g. Paulson et al., 1999; Calvert et al., 2000), (2) on the chemical origins of the biradical that may lead to different ranges of excitation energies or ratio in the syn or anti configuration (e.g. Fenske et al., 2000b; Kroll et al., 2002). Numerous studies have been devoted these last 10 years to quantify the evolution of Criegee radicals, especially with respect to $\mathrm{OH}$ radical production (e.g. Orzechowska and Paulson, 2002; Siese et al., 2001; Lewin et al., 2001; Fenske et al., 2000a; Rickard et al., 1999; Paulson et al., 1999; Calvert et al., 2000, and references therein). However, large uncertainties still remain concerning the branching ratios and, to our knowledge, no parameterization is available concerning the formation and evolution of Criegee radicals that takes into account the detailed chemical identity of the groups bonded to the biradicals or the syn/anti ratios. Fixed branching ratios are assigned in the generator for external (i.e. $-\mathrm{CH}(\cdot)(\mathrm{OO} \cdot)$ structures) and internal (i.e. $>\mathrm{C}(\cdot)(\mathrm{OO} \cdot)$ structures) biradicals, based on the SAR of Carter (2000). These branching ratios are summarized in the Table 7.

\subsection{Cyclic molecules}

As mentioned above, the chemistry of cyclic molecules is not currently implemented in the generator. The chemical schemes of several cyclic compounds (e.g. terpenes and aromatic compounds) were written manually up to the formation of ring opening products. Full oxidation of these noncyclic reaction products is then handled by the generator. The chemical scheme for cyclic compounds is based on the SAPRC-99 mechanism (Carter, 2000). 

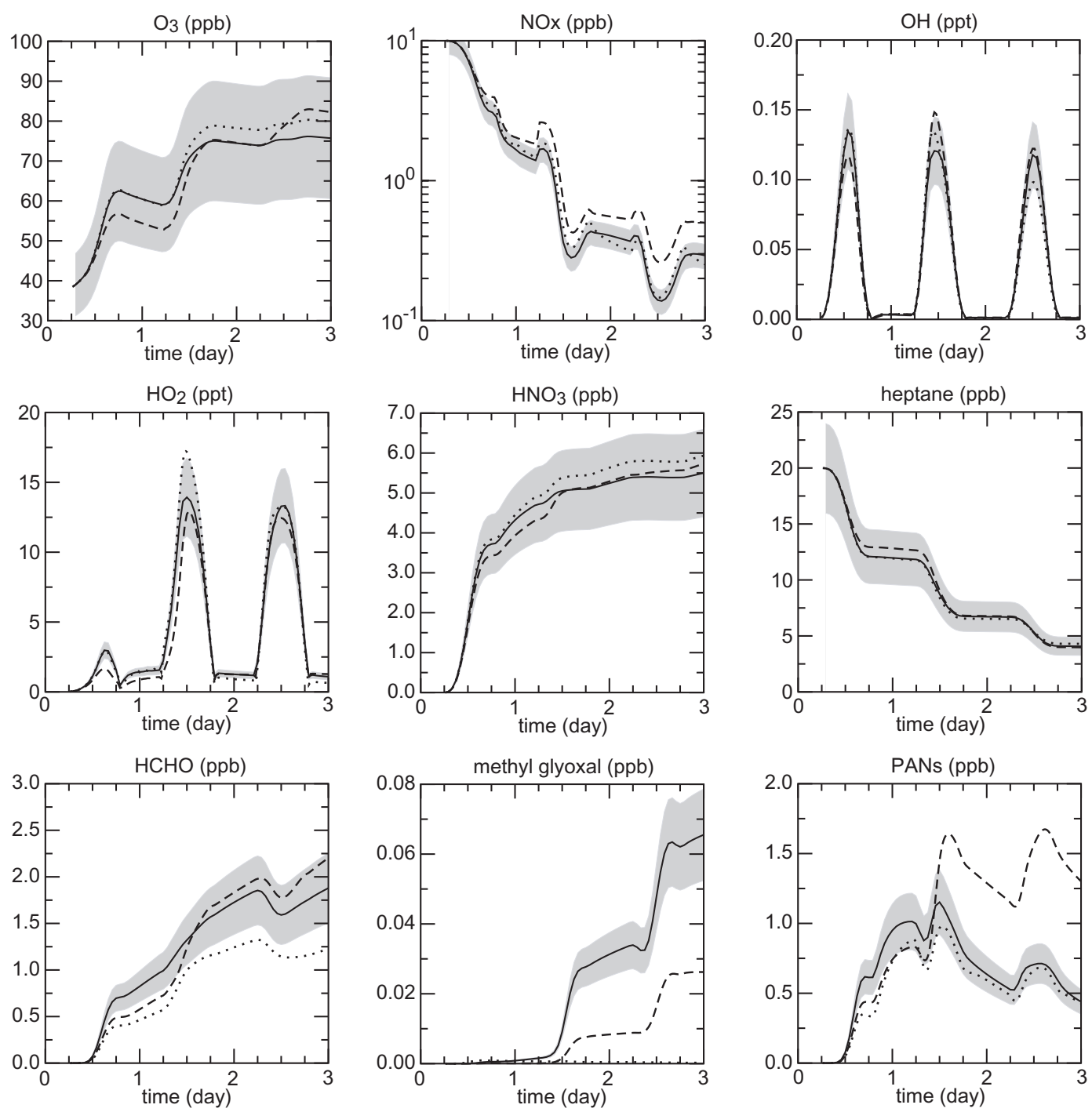

Fig. 7. Mechanism comparison for n-heptane oxidation. Solid line: generator scheme; dashed lines: MCM-v3 scheme; dotted lines: SAPRC99 scheme. The shaded area corresponds to $\pm 20 \%$ deviation around the mixing ratio simulated with the generator scheme. The SAPRC99 mechanism does not include methyl glyoxal for heptane.

\section{Evaluation of the chemical schemes}

To evaluate the schemes written by the generator, some comparisons were made with well-established chemical mechanisms: (1) the SAPRC99 scheme developed by Carter (2000) which has been developed and validated using experimental smog chamber data and (2) the master chemical mechanism (MCM-v3.1) developed at the University of Leeds (Saunders et al., 2003b; Jenkin et al., 2003) which is to our knowledge the most detailed scheme available in the literature. Both mechanisms treat the chemistry induced by a given VOC specifically and are therefore especially suitable to test the chemical schemes provided by the generator. All the schemes were implemented in the same box model and the simulations were carried out with identical conditions. Photolysis frequencies were computed for mid-latitude equinox conditions using the TUV model (Madronich and Flocke, 1998). These frequencies were assigned to the corresponding reactions according to the recommended rules for each mechanism. Furthermore, the same set of inorganic reactions was implemented in each scheme, so that differences could only be ascribed to the various organic schemes. Time integration was performed using the two-step solver developed by Verwer (1994); Verwer et al. (1996). This solver is based on the implicit second order two-step backward differentiation formula (BDF) which is solved approximately using GaussSeidel iteration. Initial mixing ratios are respectively set to 10,20 and $40 \mathrm{ppb}$ for $\mathrm{NO}_{\mathrm{x}}$, the VOC under consideration and ozone. With these conditions, the chemistry is characterized by a $\mathrm{NO}_{\mathrm{x}}$ saturated regime in the first day but a $\mathrm{NO}_{\mathrm{x}}$ limited regime on the last two days. 

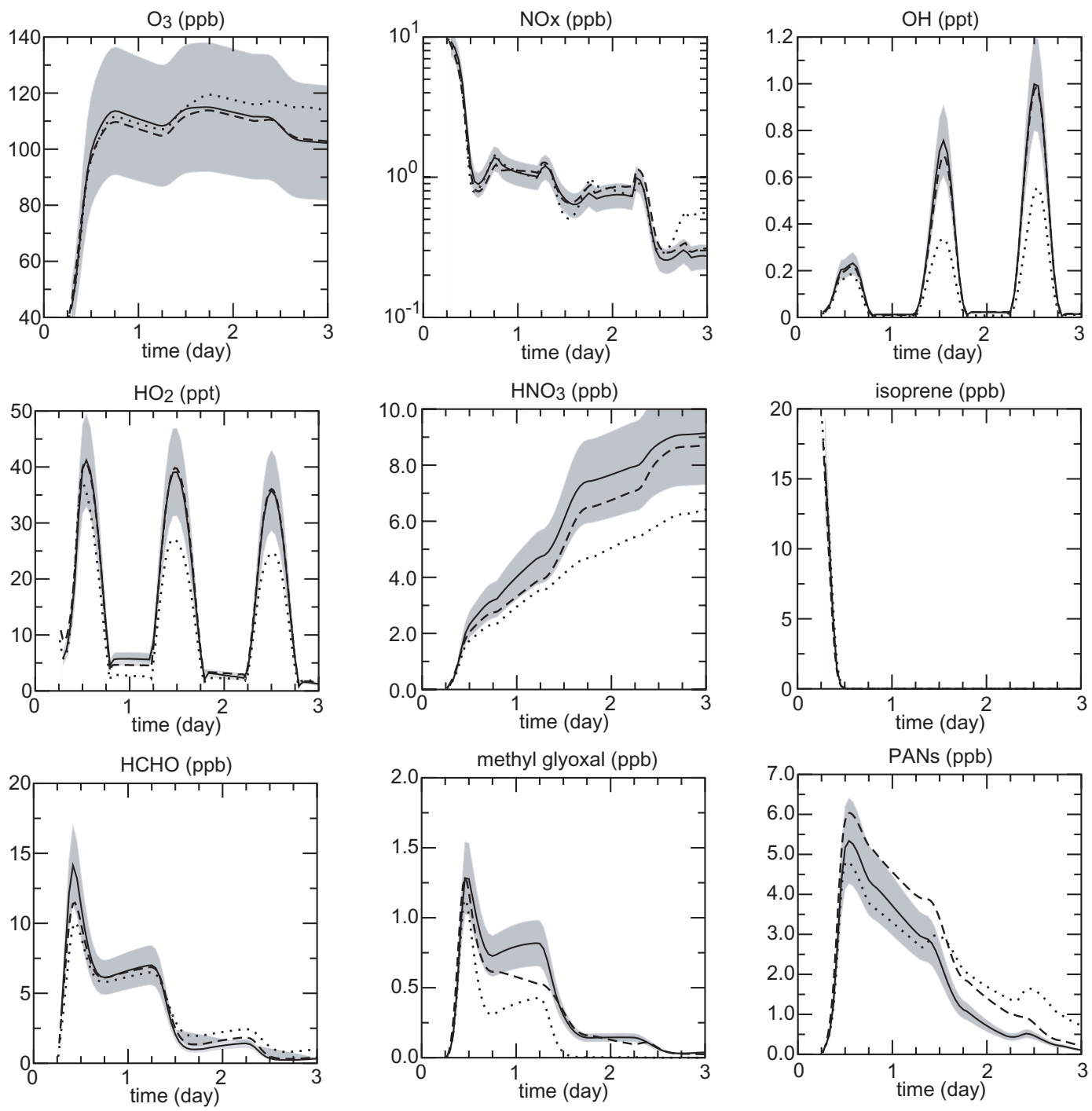

Fig. 8. Mechanism comparison for isoprene oxidation. Solid line: generator scheme; dashed lines: MCM-v3 scheme; dotted lines: SAPRC99 scheme. The shaded area corresponds to $\pm 20 \%$ deviation around the mixing ratio simulated with the generator scheme.

Figures 7 and 8 show the concentration profiles simulated for $\mathrm{n}$-heptane and isoprene, respectively. The comparisons of the profiles simulated with SAPRC99, MCM-v3.1 and the generator scheme show a fairly good agreement. For most of the tested species, mixing ratio simulated with the generator scheme match within $20 \%$ those obtained with the SAPRC99 and MCM-v3.1 schemes. In particular, an excellent agreement between the generator scheme and the SAPRC99 scheme was obtained in the case of n-heptane oxidation for the $\mathrm{O}_{3} / \mathrm{NO}_{\mathrm{x}} / \mathrm{HO}_{\mathrm{x}}$ species (see Fig. 7). On the other hand, the generator scheme was found to best match the MCM-v3.1 for the simulation using isoprene as a precursor. In that case, both mechanisms agree within few percents for the $\mathrm{O}_{3} / \mathrm{NO}_{\mathrm{x}} / \mathrm{HO}_{\mathrm{x}}$ species (see Fig. 8). As expected, the largest discrepancies were found for secondary organic species produced after many successive oxidation steps. This point is highlighted in the Figs. 7 and 8 for methyl glyoxal: the agreement with MCM-v3.1 is worse than a factor 2; no source of methyl glyoxal is considered for $n$-heptane oxidation in SAPRC99. Nevertheless, some secondary species produced with large yields like formaldehyde show a surprisingly good agreement between the 3 mechanisms, at least for the conditions tested here.

Additional tests were performed to evaluate the chemical schemes provided by the generator. These tests are presented in a companion paper (Szopa et al., 2005). All the tests performed so far did not highlight any problem or major error on the generator's code. Furthermore, no significant numerical bias was found by the time integration of the very large number of species and reactions generated (e.g. for heptane, we solved the chemistry of about $4.6 \times 10^{5}$ species and $4.5 \times 10^{6}$ reactions). 


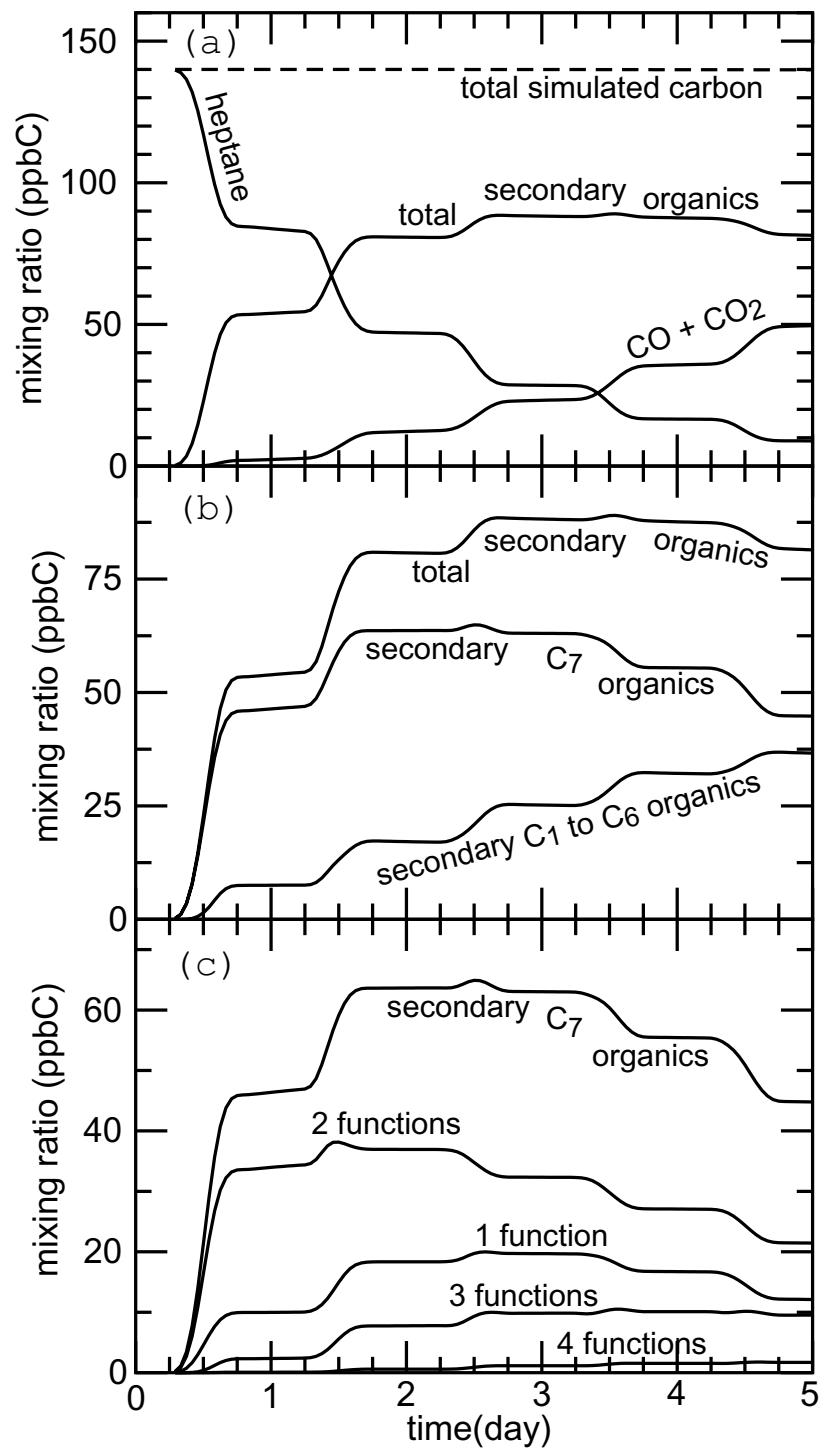

Fig. 9. Evolution of carbonaceous species during the oxidation of n-heptane. Panel (a): distribution of the carbon. Panel (b): distribution of secondary organic carbon for various chain lengths. Panel (c): distribution of secondary $\mathrm{C}_{7}$ organics as a function of the number of functional groups borne by the molecules.

\section{Example of organic budgets during gas phase oxida- tion}

Some very preliminary simulations were performed to examine the oxidation pathways of a given VOC. We present here some results obtained for the case of n-heptane with a particular focus on the gradual change of organic compounds during oxidation. To our knowledge, such simulations are the first using a fully detailed oxidation scheme. Simulation conditions are identical to those described in the previous section, except that simulation is run over 5 days.
Speciation of the primary carbon (i.e. heptane), secondary organic carbon, and inorganic carbon (i.e. $\mathrm{CO}+\mathrm{CO}_{2}$ ) is shown as a function of time in Fig. 9a. For the conditions used here, more than $90 \%$ of heptane is predicted to be removed after 5 days. However, only $20-30 \%$ of the carbon available was found to be oxidized into $\mathrm{CO}$ or $\mathrm{CO}_{2}$ at that time. Most of the carbon lies in the secondary organic fraction, which is the dominant fraction after 1.5 simulated days. Figure $9 \mathrm{~b}$ shows the distribution of secondary organic species as a function of the chain length. The secondary organic fraction is shown to be dominated by species holding 7 carbon atoms, i.e. of the same size as the parent compound. The organic carbon included in $\mathrm{C}_{1}$ to $\mathrm{C}_{6}$ species grow with time, but this fraction remains lower than the $\mathrm{C}_{7}$ fraction even after 5 days of simulated oxidation (see Fig. 9b). Figure 9c gives additional insight into the distribution of secondary $\mathrm{C}_{7}$ and shows how these species are distributed as a function of the number of functional groups borne by the molecules. Organics appear to have typically 2 or more functional groups. Henry's law coefficients for many organic compounds were recently summarized by Sander (1999). Available data shows that the Henry's law coefficient for most difunctional species typically lies in $10^{3}-10^{6} \mathrm{M} \mathrm{atm}^{-1}$ range (or higher when the number of functions is greater than 2). For a typical liquid water content of $L=10^{-6} \mathrm{~g} \mathrm{~m}^{-3}$ in clouds, species in that range can be classified as moderately to very soluble (Seinfeld and Pandis, 1998), i.e. dissolving from significantly to almost totally in cloud droplets at thermodynamical equilibrium. These results thus strongly suggest that a significant fraction of the secondary organic carbon would dissolve into water droplets during cloud events. Furthermore, a nonnegligible fraction of $\mathrm{C}_{7}$ organics is found to bear at least 4 functional groups (see Fig. 9c). Vapor pressure estimates using the Myrdal and Yalkowsky (1997) group contribution method lead to extremely low vapor pressure for these kinds of species, typically in the range of $10^{-10}$ to $10^{-7} \mathrm{~atm}$. These compounds may thus be candidate compounds for the formation of Secondary Organic Aerosols (SOA).

The distribution of the different organic moieties is shown as a function of time in the Fig. 10. The results are expressed as a functional group per organic carbon ratio $\left(\mathrm{R}_{\mathrm{OF} / \mathrm{C}}\right)$. About $30 \%$ of the organic carbon is found to be substituted after 5 days (see Fig. 10). The dominant functionality is the ketone group $\left(\mathrm{R}_{-\mathrm{CO}-/ \mathrm{C}}=5-15 \%\right)$, with a significant contribution of the alcohol and nitrate groups $\left(\mathrm{R}_{\mathrm{ROH} / \mathrm{C}} \approx \mathrm{R}_{\mathrm{RONO} / \mathrm{C}} \approx 2-4 \%\right)$. As previously stated, oxidation during the first day occurs in a $\mathrm{NO}_{\mathrm{x}}$ saturated regime (i.e. the $\mathrm{RO}_{2}+\mathrm{NO}$ is the dominant reaction for peroxy radicals). The hydroperoxide, peracid and carboxylic acid moieties were found to be negligible during the first day, in agreement with the chemistry expected for a $\mathrm{NO}_{\mathrm{x}}$ saturated regime. These moieties appear to be significant only after the second day, when the $\mathrm{NO}_{\mathrm{x}}$ limited regime is reached. Finally, the carboxylic acid moiety was found to be one of the major groups after 5 days. This is a particularly interesting 


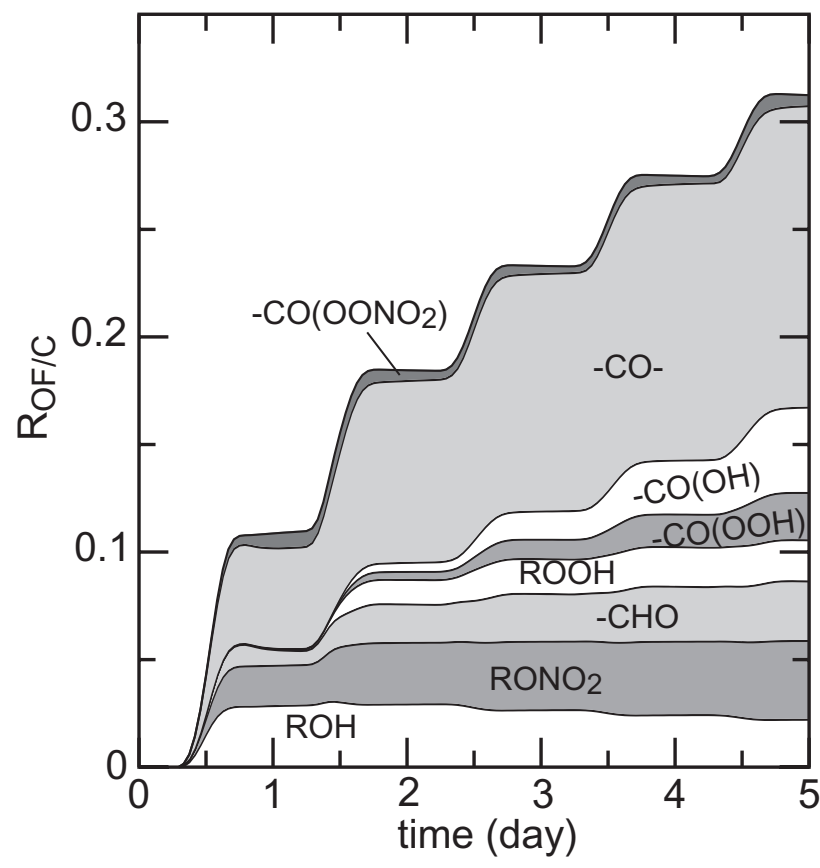

Fig. 10. Evolution of the organic functionalities to carbon ratio $\left(\mathrm{R}_{\mathrm{OF} / \mathrm{C}}\right)$ during the oxidation of n-heptane.

outcome since the carboxylic acid functional group is highly water-soluble and decreases to a large extent the vapor pressure of the species. Carboxylic acids were measured to be a major functional group in organic aerosols (e.g. Sempere and Kawamura, 1994) and have been suggested as key compounds for organic aerosol nucleation, especially in the diacidic form (Hoffmann et al., 1998). Some representative $\mathrm{C}_{7}$ secondary organics predicted during heptane oxidation are reported in the Table 8 . The contribution of the species to each group listed in the Table 8 was predicted to be above a few percents.

The nitrogen budget during the n-heptane oxidation is shown in the Fig. 11. About $30 \%$ of the initial $\mathrm{NO}_{\mathrm{x}}$ load was found to be held as organic nitrate during the first day (i.e. in the $\mathrm{NO}_{\mathrm{x}}$ saturated regime). As expected, secondary organics are shown to be potentially key contributors to the long range transport of nitrogen oxides (if not removed by dry or wet deposition when included in multifunctional species).

Although very preliminary, these results are very promising and show the benefit of explicit schemes for modeling the evolution of organic compound during oxidation. These results also highlight the potential of the self generating approach for the development of multiphase organic chemical schemes.

\section{Conclusions}

The development of explicit chemical schemes is a necessary step to test our current understanding of the evolution

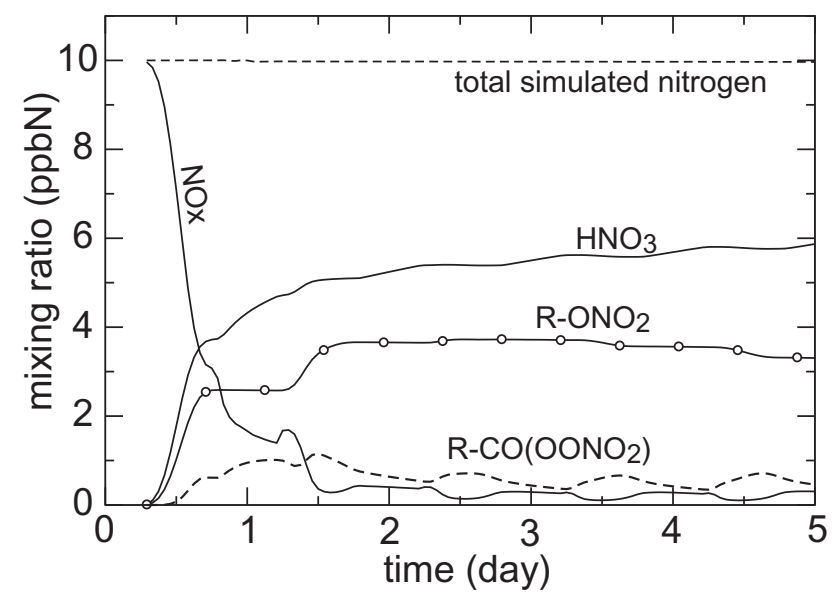

Fig. 11. Evolution of the major nitrogen compounds during the oxidation of n-heptane.

and impact of organic carbon during its atmospheric oxidation. However, the myriad of intermediates involved preclude any attempt to describe the numerous physical and chemical transformations manually. Data processing tools are required to (1) assimilate the various experimental data provided by laboratory studies (2) codify the various estimation methods, and (3) generate consistent, comprehensive oxidation schemes on a systematic basis.

We showed in this study that a self generating approach can be used to generate explicit gas-phase oxidation schemes.

A very promising application of the generator is the modelling of secondary organic aerosol formation. Current models describing SOA formation are developed on an empirical approach, based on yields measured in smog chambers (e.g. Odum et al., 1997; Hoffmann et al., 1997; Schell et al., 2001) and justify the development of exploratory models describing in detail the various processes leading to SOA formation (Griffin et al., 2002, 2003; Pun et al., 2002; Jenkin, 2004). The main difficulties lie in describing the sources and sinks of the myriad of VOC that may contribute to SOA and their thermodynamic equilibrium with the condensed phases. The generator is clearly a powerful tool to study SOA formation by its ability to explicitly describe the chemical dynamics of the various precursors.

Furthermore, organic chemistry inside cloud droplets raises many questions, e.g. its role in the $\mathrm{O}_{\mathrm{x}} / \mathrm{HO}_{\mathrm{x}}$ budget, the formation of organic acids and organic aerosols after the evaporation of the cloud droplets, and the atmospheric removal of organic matter. Answering these kind of questions by a modelling approach clearly requires the development of chemical schemes describing the organic oxidation in the aqueous phase. Currently, laboratory studies dealing with the oxidation in atmospheric aqueous phases are receiving increasing interest and the available kinetic database for these processes is becoming substantial. Extension of the self 
generating approach to model multiphase system would provide a valuable exploratory tool to assess the role of clouds in the evolution of organic compounds.

Acknowledgements. We are thankful to W. P. L. Carter, M. Jenkin, S. Saunders and co-workers for providing downloadable version of the SAPRC and MCM mechanisms. J. Calvert, L. Sanford, and C. Rosselet contributed to the early development of the generator at NCAR. NCAR is sponsored by the National Science Foundation.

Edited by: U. Lohmann

\section{References}

Atkinson, R.: Kinetics and mechanisms of the gas-phase reactions of $\mathrm{NO} 3$ radical with organic compounds, J. Phys. Chem. Ref. Data, 20, 459-508, 1991.

Atkinson, R.: Gas-Phase Tropospheric Chemistry of Organic Compounds, J. Phys. Chem. Ref. Data, Monograph, 2, 1-216 1994.

Atkinson, R.: Gas-phase tropospheric chemistry of VOC.1. Alkanes and alkenes, J. Phys. Chem. Ref. Data, 26, 215-290, 1997.

Atkinson, R.: Atmospheric chemistry of VOCs and $\mathrm{NO}_{\mathrm{x}}$, Atmos. Envir., 34, 2063-2101, 2000.

Atkinson, R. and Arey, J.: Atmospheric degradation of volatile organic compounds, Chem. Rev., 103, 4605-4638, 2003.

Atkinson, R., Baulch, D. L., Cox, R. A., Hampson, R. F., Kerr, J. A., and Rossi, M.: Evaluated kinetics and photochemical data for atmospheric chemistry, Supplement V., J. Phys. Chem. Ref. Data, 26, 521-1011, 1997.

Atkinson, R., Baulch, D. L., Cox, R. A., Hampson, R. F., Kerr, J. A., and Rossi, M. J.: Evaluated kinetics and photochemical data for atmospheric chemistry, Organic species, Supplement VII, J. Phys. Chem. Ref. Data, 28, 191-392, 1999.

Aumont, B., Madronich, S., Bey, I., and Tyndall, G. S.: Contribution of secondary VOC to the composition of aqueous atmospheric particles: a modeling approach, J. Atmos. Chem., 35, 59-75, 2000.

Bacher, C., Tyndall, G. S., and Orlando, J. J.: The atmospheric chemistry of glycolaldehyde, J. Atmos. Chem., 39, 171-189, 2001.

Benson, S. W.: Thermodynamical kinetics, John Wiley and Sons, New York, 1976.

Bey, I., Aumont, B., and Toupance, G.: A modeling study of the nighttime radical chemistry in the lower continental troposphere 1. Development of a detailed chemical mechanism including nighttime chemistry, J. Geophys. Res., 106, 9959-9990, 2001.

Bierbach, A., Barnes, I., Becker, K. H., and Wiesen, E.: Atmospheric chemistry of unsaturated carbonyls: butenedial, 4-oxo-2pentenal, 3-hexene-2,5-dione, maleic anhydre, 3H-furan-2-one, and 5-methyl-3H-furan-2-one, Environ. Sci. Technol., 28, 715729, 1994.

Blando, J. D. and Turpin, B. J.: Secondary organic aerosol formation in cloud and fog droplets: a literature evaluation of plausibility, Atmos. Environ., 34, 1623-1632, 2000.

Bowman, F. M., Odum, J. R., Seinfeld, J. H., and Pandis, S. P.: Mathematical model for gas-particle partitioning of secondary organic aerosols, Atmos. Environ., 23, 3921-3931, 1997.

Boyd, A. A., Villenave, E., and Lesclaux, R.: Structure-reactivity relationships for the self-reactions of linear secondary alkylper- oxy radicals: an experimental investigation, Int. J. Chem. Kinet., 31, 37-46, 1999.

Boyd, A. A., Flaud, P. M., Daugey, N., and Lesclaux, R.: Rate constant for $\mathrm{RO} 2+\mathrm{HO} 2$ reactions measured under a large excess of $\mathrm{HO}_{2}$, J. Phys. Chem. A, 107, 818-821, 2003.

Brasseur, G., Hauglustaine, D. A., Walters, S., Rasch, P. J., Muller, J. F., Granier, C., and Tie, X. X.: MOZART, a global chemical transport model for ozone and related chemical tracers, 1 . Model description, J. Geophys. Res., 103, 28 265-28 289, 1998.

Cabanas, B., Salgado, S., Martin, P., Baeza, M. T., and Martinez, E.: Nighttime atmospheric loss process for unsaturated aldehydes: reaction with NO3 radicals, J. Phys. Chem. A, 105, 4440-4445, 2001.

Calvert, J. G., Atkinson, R., Kerr, J. A., Madronich, S., Moortgat, G., Wallington, T. J., and Yarwood, G.: The mechanisms of atmospheric oxidation of the alkenes, Oxford University Press, New York, 2000.

Canosa-Mas, C. E., King, M. D., Lopez, R., Percival, C. J., Wayne, R. P., Shallcross, D. E., Pyle, J. A., and Daële, V.: Is the reaction between $\mathrm{CH} 3 \mathrm{C}(\mathrm{O}) \mathrm{O} 2$ and $\mathrm{NO} 3$ important in the nighttime troposphere, J. Chem. Soc. Faraday Trans., 92, 2211-2222, 1996.

Carter, W. P. L.: Documentation of the SAPRC-99 chemical mechanism for the VOC reactivity assessment, Final Report to the California Air Resources Board under Contracts 92-329 and 95-308, Center of Environmental Research and Technology, Riverside, http://pah.cert.ucr.edu/ carter/SAPRC99.htm, 2000.

Carter, W. P. L. and Atkinson, R.: Development and evaluation of a detailed mechanism for the atmospheric reactions of isoprene and NOx, Int. J. Chem. Kinet., 28, 497-530, 1996.

Chew, A. A., Atkinson, R., and Aschmann, S. M.: Kinetics of the gas-phase reactions of NO3 radicals with a series of alcohols, glycol ethers, ethers and chloroalkenes, J. Chem. Soc. Faraday Trans., 94, 1083-1089, 1998.

D’Anna, B., Andresen, W., Gefen, Z., and Nielsen, C. J.: Kinetic study of $\mathrm{OH}$ and NO3 radical reactions with 14 aliphatic aldehydes, Phys. Chem. Chem. Phys., 3, 3057-3063, 2001.

De More, W. B., Molina, M. J., Sander, S. P., Golden, D. M., Hampson, R. F., Kurylo, M. J., Howard, C. J., Kolb, C. E., and Ravishankara, A. R.: Chemical Kinetics and photochemical data for use in stratospheric modeling, JPL Pub. 97-4, Jet Propulsion Laboratory, California Institute of Technology, Pasadena, California, 1997.

Desai, J., Heicklen, J., Bahta, A., and Simonatis, R.: The photooxidation of i-C3H7CHO vapour, J. Photochem., 34, 137-164, 1986.

Ervens, B., George, C., Williams, J. E., Buxton, G. V., Salmon, G. A., Bydder, M., Wilkinson, F., Dentener, F., Wolke, R., and Herrmann, H.: CAPRAM 2.4 (MODAC mechanism): an extended and condensed tropospheric aqueous phase mechanism and its application, J. Geophys. Res., 108(D14), 4426, doi:10.1029/2002JD002202, 2003.

Facchini, M. C., Mircea, M., Fuzzi, S., and Charlson, R. J.: Cloud albedo enhancement by surface-active organic solutes in growing droplets, Nature, 401, 257-259, 1999.

Facchini, M. C., Decesari, S., Mircea, M., Fuzzi, S., and Loglio, G.: Surface tension of atmospheric wet aerosol and cloud/fog droplets in relation to their organic carbon content and chemical composition, Atmos. Environ., 34, 4853-4857, 2000. 
Faust, B. C.: Photochemisry of clouds, fogs, and aerosols, Environ. Sci. Technol., 28, 217A-222A, 1994.

Fenske, J. D., Kuwata, K. T., Houk, K. N., and Paulson, S. E.: $\mathrm{OH}$ radical yield from the ozone reaction with cycloalkenes, J. Phys. Chem. A, 104, 7246-7254, 2000a.

Fenske, J. D., Hasson, A. S., Paulson, S. E., Kuwata, K. T., Ho, A., and Houk, K. N.: The pressure dependence of the $\mathrm{OH}$ radical yield from ozone-alkene reactions, J. Phys. Chem. A, 104, 78217833, 2000b.

Finlayson-Pitts, B. J. and Pitts, J. N.: Chemistry of the upper and lower atmosphere, Academic Press, San Diego, 2000.

Gery, M. W., Whitten, G. Z., Killus, J. P., and Dodge, M. C.: A photochemical kinetics mechanism for urban and regional scale computer modeling, J. Geophys. Res., 94, 12 925-12 959, 1989.

Griffin, R. J., Dabdub, D., and Seinfeld, J. H.: Secondary organic aerosol, I, Atmospheric chemical mechanism for production of molecular constituents, J. Geophys. Res., 107, 4332, doi:10.1029/2001JD000541, 2002.

Griffin, R. J., Nguyen, K., Dabdub, D., and Seinfeld, J. H.: A coupled hydrophobic-hydrophilic model for predicting secondary organic aerosol formation, J. Atmos. Chem., 44, 171-190, 2003.

Grosjean, E. and Grosjean, D.: Rate constant for the gas-phase reaction of ozone with unsaturated oxygenates, Int. J. Chem. Kinet., 30, 21-29, 1998.

Hoffmann, T., Odum, J. R., Bowman, F., Collins, D., Klockow, D., Flagan, R. C., and Seinfeld, J. H.: Formation of organic aerosols from the oxidation of biogenic hydrocarbons, J. Atmos. Chem., 26, 189-222, 1997.

Hoffmann, T., Bandur, R., Marggraf, U., and Linscheid, M.: Molecular composition of organic aerosols formed in the alphapinene/O3 reaction: implication for new particle formation processes, J. Geophys. Res., 103, 25 569-25 578, 1998.

Jacobson, M. Z.: Isolating nitrated and aromatic aerosols and nitrated aromatic gases as sources of ultraviolet light absorption, J. Geophys. Res., 104, 3527-3542, 1999.

Jenkin, M. E.: Modelling the formation and composition of secondary organic aerosol from alpha- and beta-pinene ozonolysis using MCM v3, Atmos. Chem. Phys., 4, 1741-1757, 2004,

\section{SRef-ID: 1680-7324/acp/2004-4-1741}

Jenkin, M. E., Saunders, S. M., and Pilling, M. J.: The tropospheric degradation of volatile organic compounds: a protocol for mechanism development, Atmos. Environ., 31, 81-104, 1997.

Jenkin, M. E., Saunders, S. M., Wagner, V., and Pilling, M. J.: Protocol for the development of the Master Chemical Mechanism, MCM v3 (Part B): tropospheric degradation of aromatic volatile organic compounds, Atmos. Chem. Phys., 3, 181-193, 2003,

SRef-ID: 1680-7324/acp/2003-3-181.

Kalberer, M., Paulsen, D., Sax, M., Steinbacher, M., Dommen, J., Prevot, A. S. H., Fisseha, R., Weingartner, E., Frankevich, V., Zenobi, R., and Baltensperger, U.: Identification of polymers as major components of atmospheric organic aerosols, Science, 303, 1659-1662, 2004.

Klotz, B., Bierbach, A., Barnes, H. M., and Becker, K. H.: Kinetic and mechanistic study of the atmospheric chemistry of muconaldehydes, Environ. Sci. Technol., 29, 2322-2332, 1995.

Klotz, B., Barnes, I., and Becker, K. H.: Kinetic study of the gas-phase photolysis and $\mathrm{OH}$ radical reaction of EZ-2.4hexadienedial, Int. J. Chem. Kinet., 31, 689-697, 1999.
Koch, S. and Moortgat, G.: Photochemistry of methylglyoxal in the vapor phase, J. Phys. Chem. A, 102, 9142-9153, 1998.

Kroll, J. H., Donahue, N. M., Cee, V. J., Demerdjian, K. L., and Anderson, J. G.: Gas phase ozonolysis of alkenes: formation of $\mathrm{OH}$ from anti carbonyl oxides, J. Am. Chem. Soc., 124, 85188519, 2002.

Kwok, E. S. C. and Atkinson, R.: Estimation of the hydroxyl radical reaction rate constants for gas-phase organic compounds using a structure-reactivity relationship: an update, Atmos. Environ., 29, 1685-1695, 1995.

Kwok, E. C., Arey, J., and Atkinson, R.: Product formation from the reaction of the $\mathrm{NO} 3$ radical with isoprene and rate constants for the reactions of methacroleine and MVK with the $\mathrm{NO}_{3}$ radical, Int. J. Chem. Kinet., 28, 925-934, 1996.

Laval-Szopa, S.: Développement d'une chaine automatique d'écriture de schémas chimiques explicites et réduits adaptés à l'étude de la pollution photooxydante, $\mathrm{PhD}$ thesis, University of Paris XII, December 2003, available at http://tel.ccsd.cnrs.fr/ documents/archives0/00/00/65/99/index.html, 2003.

Lesclaux, R.: Combination of peroxyl radicals in the gas phase, in: Peroxyl Radicals, edited by: Alfassi, Z. B., 81-112, John Wiley, New York, 1997.

Lewin, A. G., Johnson, D., Price, D. W., and Marston, G.: Aspects of the kinetics and mechanism of the gas-phase reactions of ozone with conjugated dienes, Phys. Chem. Chem. Phys., 3, 1253-1261, 2001.

Liu, X. H. E., Jeffries, H. E., and Sexton, K. G.: Atmospheric Photochemical Degradation of 1.4-unsatured dicarbonyls, Environ. Sci. Technol., 33, 4212-4220, 1999.

Lohmann, U., Broeckhuizen, K., Leaitch, R., Shantz, N., and Abbatt, J.: How efficient is cloud droplet formation of organic aerosols?, Geophys. Res. Lett., 31, L05108, doi:10.1029/2003GL018999, 2004

Madronich, S. and Calvert, J. G.: Permutation reactions of organic peroxy radicals in the troposphere, J. Geophys. Res., 95, 56975715, 1990.

Madronich, S. and Flocke, S.: The role of solar radiation in atmospheic chemistry, in: Handbook of environmental chemistry, edited by: Boule, P., 1-26, Springer, New York, 1998.

Magneron, L., Tadic, J., Sauer, F., and Moortgat, G.: Photolytic studies on glyoxal, crotonaldehyde, acroleine and glycolaldehyde, in: Proceedings of the EC/Eurotrac joint workshop, edited by: Vogt, R. and Axelsdottir, G., 66-69, ISBN 3-00-005414-6, Aachen, 1999.

Martinez, R. D., Buitrago, A. A., Howell, N. W., Hearn, C. H., and Joens, J. A.: The near UV absorption spectra of several aliphatic aldehydes and ketones at $300 \mathrm{~K}$, Atmos. Environ., 26, 785-792, 1992.

Mellouki, A., Le Bras, G., and Sidebottom, H.: Kinetics and mechanisms of the oxidation of oxygenated organic compounds in the gas phase, Chem. Rev., 103, 5077-5096, 2003.

Monod, A. and Carlier, P.: Impact of clouds on the troposheric ozone budget: direct effect of multiphase photochemistry of soluble organic compounds, Atmos. Environ., 33, 4431-4446, 1999.

Moortgat, G., Wirtz, K., Pons, N., Jensen, N., Horth, J., Winterhalter, R., Ruppert, L., Magneron, L., Tadic, J., and Mellouki, A.: Trends in tropospheric photodissociation rates of selected carbonyl compounds, in: Proceedings of the EC/Eurotrac-2 joint 
workshop, edited by: Vogt, R. and Axelsdottir, G., 28-31, ISBN 3-00-005414-6, Aachen, 1999.

Myrdal, P. B. and Yalkowsky, S. H.: Estimating pure component vapor pressures of complex organic molecules, Ind. Eng. Chem. Res., 36, 2494-2499, 1997.

Neeb, P., Kolloff, A., Koch, S., and Moortgat, G.: Rate Constants for the Reactions of Methylvinyl Ketone, Methacrolein, Methacrylic Acid, and Acrylic Acid with Ozone, Int. J. Chem. Kinet., 30, 769-776, 1998.

Odum, J. R., Jungkamp, T. P. W., Griffin, R. J., Flagan, R. C., and Seinfeld, J. H.: The atmospheric aerosol forming potential of whole gasoline vapor, Science, 276, 96-99, 1997.

Orlando, J. J. and Tyndall, G. S.: The atmospheric chemistry of the HC(O)CO radical, Int. J. Chem. Kinet., 33, 149-156, 2001.

Orlando, J. J., Tyndall, G. S., Fracheboud, J.-M., Estupinan, E. G., Haberkorn, S., and Zimmer, A.: The rate and mechanism of gasphase oxidation of hydroxyacetone, Atmos. Environ., 33, 16211629, 1999.

Orlando, J. J., Tyndall, G. S., and Wallington, T. J.: The atmospheric chemistry of alkoxy radicals, Chem. Rev., 103, 46574689, 2003.

Orzechowska, G. E. and Paulson, S. E.: Production of $\mathrm{OH}$ radicals from the reactions of C4-C6 internal alkenes and styrenes with ozone in the gas phase, Atmos. Environ., 36, 571-581, 2002.

Pankow, J. F., Seinfeld, J. H., Asher, W. E., and Erdakos, G. B.: Modeling the formation of secondary organic aerosol, 1. Application of theoretical principles to measurements obtained in the alpha-pinene/, beta-pinene/, sabinene/, delta3-carene/, and cyclohexene/Ozone systems, Environ. Sci. Technol., 35, 1164-1172, 2001.

Paulson, S. E., Chung, M. Y., and Hasson, A. S.: OH radical formation from the gas-phase reaction of ozone with terminal alkenes and the relationship between structure and mechanism, J. Phys. Chem. A, 103, 8125-8138, 1999.

Peeters, J., Vertommen, J., Langhans, I., Boullart, W., Van Hoeymissen, J., and Pultau, V.: Kinetic studies of reactions of alkylperoxy and haloalkylperoxy radicals with NO, A structure activity relationship for reactions of $\mathrm{OH}$ with alkenes and polyalkenes, in: Chemical processes in atmospheric oxidation, edited by: LeBras, G., Springer, Berlin, 179-185, 1997.

Plum, C. N., Sanhueza, E., Atkinson, R., Carter, W. P. L., and Pitts, J. N.: OH radical rate constants and photolysis rates of alphadicarbonyls, Environ. Sci. Technol., 17, 479-484, 1983.

Poisson, N., Kanakidou, M. A., and Crutzen, P. J.: Impact of NonMethane Hydrocarbons on tropospheric chemistry and the oxidizing power of the global troposphere: 3-Dimensional Modelling Results, J. Atmos. Chem., 36, 157-230, 2000.

Pun, B. K., Griffin, R. J., Seigneur, C., and Seinfeld, J. H.: Secondary organic aerosol, II, Thermodynamic model for gas/particule partitioning of molecular constituents, J. Geophys. Res., 4333, doi:10.1029/2001JD000542, 2002.

Raber, W. H. and Moortgat, G. K.: Photooxidation of selected carbonyl compounds in air: methyl ethyl ketone, methyl vinyl ketone, methacroleine, and methylglyoxal, in: Progress and problems in atmospheric chemistry, edited by: Barker, J. R., World Scientific Publishing, Singapore, 318-373, 1995.

Rickard, A. R., Johnson, D., McGill, C. D., and Marston, G.: $\mathrm{OH}$ yields in the gas-phase reactions of ozone with alkenes, J. Phys. Chem. A, 103, 7656-7664, 1999.
Roberts, J. M. and Fajer, R. W.: UV absorption cross sections of organic nitrates of potential atmospheric importance and estimation of atmospheric lifetimes, Environ. Sci. Technol., 23 (8), 945-951, 1989.

Rudich, Y., Talukdar, R. K., Fox, R. W., and Ravishankara, A. R.: Rate coefficients for the reactions of $\mathrm{NO}_{3}$ with a few olefins and oxygenated olefins, J. Phys. Chem., 100, 5374-5381, 1996.

Sander, R.: Compilation of Henry's law constants for inorganic and organic species of potential importance in environmental chemistry (Version 3), http://www.mpch-mainz.mpg.de/ sander/res/ henry.html, 1999.

Sander, S. P., Friedl, R. R., De More, W. B., Golden, D. M., Kurylo, M. J., Hampson, R. F., Huie, R. E., Moortgat, G., Ravishankara, A. R., Kolb, C. E., and Molina, L. T.: Chemical kinetics and photochemical data for use in stratospheric modeling, Jet Propulsion Laboratory, Pasadena, California, 2000.

Saunders, S. M., Jenkin, M. E., Derwent, R. G., and Pilling, M. J.: www site of a master chemical mechanism (MCM) for use in tropospheric chemistry models, Atmos. Environ., 31, 1249, 1997.

Saunders, S. M., Pascoe, S., Johnson, A. P., Pilling, M. J., and Jenkin, M. E.: Development and preliminary test results of an expert system for the automatic generation of tropospheric VOC degradation mechanisms, Atmos. Environ., 37, 1723-1735, 2003a.

Saunders, S. M., Jenkin, M. E., Derwent, D., and Pilling, M. J.: Protocol for the development of the Master Chemical Mechanism, MCM v3 (Part A): tropospheric degradation of non-aromatic volatile organic compounds, Atmos. Chem. Phys., 3, 161-180, 2003b,

\section{SRef-ID: 1680-7324/acp/2003-3-161}

Saxena, P., Hildemann, L. M., McMurry, P. H., and Seinfeld, J. H.: Organics alter hygroscopic behavior of atmospheric particles, J. Geophys. Res., 100, 18 755-18770, 1995.

Schell, B., Ackermann, I. J., Hass, H., Binkowski, F. S., and Ebel, A.: Modeling the formation of secondary organic aerosol within a comprehensive air quality model system, J. Geophys. Res., 106, 28 275-28 293, 2001.

Seinfeld, J. H. and Pandis, S. N.: Atmospheric Chemistry and Physics, Wiley, New York, 1998.

Sempere, R. and Kawamura, K.: Comparative distributions of dicarboxylic acids and related polar compounds in snow, rain, and aerosols from urban atmosphere, Atmos. Environ., 28, 449-459, 1994.

Shantz, N., Leaitch, R., and Gaffrey, P. F.: Effect of organics of low solubility on the growth rate of cloud droplets, J. Geophys. Res., 108(D5), 4168, doi:10.1029/2002JD002540, 2003.

Siese, M., Becker, K. H., Brockmann, K. J., Geiger, H., Hofzumahaus, A., Holland, F., Milhelcic, D., and Wirtz, K.: Direct measurement of $\mathrm{OH}$ radicals from ozonolysis of selected alkenes: a EUPHORE simulation chamber study, Environ. Sci. Technol., 35, 4660-4667, 2001.

Stockwell, W. R., Middleton, P., Chang, J. S., and Tang, X.: The second generation regional acid deposition model chemical mechanism for regional air quality modeling, J. Geophys. Res., 95, 16343-16367, 1990.

Stockwell, W. R., Kirchner, F., Kuhn, M., and Seefeld, S.: A new mechanism for regional atmospheric chemistry modeling, J. Geophys. Res., 102, 25 847-25 879, 1997. 
Szopa, S., Aumont, B., and Madronich, S.: Assessment of the reduction methods used to develop chemical schemes: building of a new chemical scheme for VOC oxidation suited to three-dimensional multiscale $\mathrm{HO}_{\mathrm{x}}-\mathrm{NO}_{\mathrm{x}}-\mathrm{VOC}$ chemistry simulations, Atmos. Chem. Phys., 5, 2519-2538, 2005,

SRef-ID: 1680-7324/acp/2005-5-2519.

Verwer, J. G.: Gauss-Seidel iteration for stiff ODEs from chemical kinetics, SIAM Journal on Scientific Computing, 15, 1243-1250, 1994.

Verwer, J. G., Blom, J. G., Van Loon, M., and Spee, E. J.: A comparison of stiff ODE solvers for atmospheric chemistry problems, Atmos. Environ., 30, 49-58, 1996.

Villenave, E., Lesclaux, R., Seefeld, S., and Stockwell, W. R.: Kinetics and Atmospheric implications of peroxy radical cross reactions involving the $\mathrm{CH}_{3} \mathrm{C}(\mathrm{O}) \mathrm{O}_{2}$ Radical, J. Geophys. Res., 103, 25 273-25 285, 1998.

Tolocka, M. P., Jang, M., Ginter, J. M., Cox, F. J., Kamens, R. M., and Johnston, M. V.: Formation of oligomers in secondary organic aerosol, Environ. Sci. Technol., 38, 1428-1434, 2004.

Tomas, A., Villenave, E., and Lesclaux, R.: Reactions of the $\mathrm{HO}_{2}$ radical with $\mathrm{CH}_{3} \mathrm{CHO}$ and $\mathrm{CH}_{3} \mathrm{CO}\left(\mathrm{O}_{2}\right)$ in the gas phase, J. Phys. Chem. A, 105, 3505-3514, 2001.

Troe, J.: Analysis of the temperature and pressure dependance of the reaction $\mathrm{HO}+\mathrm{NO}_{2}+\mathrm{M} \rightarrow \mathrm{HONO}_{2}+\mathrm{M}$, Int. J. Chem. Kinet., $33,878-889,2001$.
Tuazon, E. C. and Atkinson, R.: A product study of the gas-phase reaction of methyl vinyl ketone with the $\mathrm{OH}$ radical in the presence of $\mathrm{NO}_{\mathrm{x}}$, Int. J. Chem. Kinet., 21, 1141-1152, 1989.

Tuazon, E. C. and Atkinson, R.: A product study of the gas-phase reaction of methacrolein with the $\mathrm{OH}$ radical in the presence of NOx, Int. J. Chem. Kinet., 22, 591-602, 1990.

Tyndall, G. S., Cox, R. A., Granier, C., Lesclaux, R., Moortgat, G. K., Pilling, M. J., Ravishankara, A. R., and Wallington, T. J.: Atmospheric chemistry of small organic peroxy radicals, J. Geophys. Res., 106, 12 157-12 182, 2001.

Wolf, A., Deutsch, F., Hoffmann, P., and Ortner, H. M.: The influence of oxalate on Fe-catalysed S(IV) oxidation by oxygen in aqueous solution, J. Atmos. Chem., 37, 125-135, 2000.

Yujing, M. and Mellouki, A.: The near-UV absorption cross sections for several ketones, J. Photochem. Photobiol., 134, 31-36, 2000.

Zhu, L. and Kellis, D.: Temperature dependance of the UV absorption cross sections and photodissociation products of C3-C5 alkyl nitrates, Chem. Phys. Lett., 278, 41-48, 1997.

Zhu, L., Cronin, T., and Narang, A.: Wavelenght-dependant photolysis of i-pentanal and t-pentanal from 280 to $330 \mathrm{~nm}$, J. Phys. Chem. A, 103, 7248-7253, 1999. 